\title{
DIFFERENT ROLES OF CALCIUM SIGNALING IN THE GATROINTESTINAL TRACT
}

\author{
Lajos Kemény, M.D.
}

\section{Ph.D. Thesis}

Supervisors: $\quad$ Viktória Venglovecz, Ph.D.

Péter Hegyi, M.D., Ph.D., D.Sc

First Department of Medicine

University of Szeged

Szeged, Hungary

2014 


\section{Articles closely related to the subject of the thesis}

I. Kemény LV*, Schnúr A*, Czepán M, Rakonczay Z Jr, Gál E, Lonovics J, Lázár G, Simonka Z, Venglovecz V, Maléth J, Judák L, Németh IB, Szabó K, Almássy J, Virág L, Geisz A, Tiszlavicz L, Yule DI, Wittmann T, Varró A, Hegyi P. Na+/Ca2+ exchangers regulate the migration and proliferation of human gastric myofibroblasts. Am. J. Physiol. Gastrointest. Liver Physiol. 305(8):G552-63. (2013) [IF: 3.737]

*The first two authors contributed equally.

II. József Maléth, Zsolt Balla, Balázs Kui, Anita Balázs, Máté Katona, Linda Judák, István Németh, Petra Pallagi, Lajos V. Kemény, Zoltán Rakonczay Jr., Viktória Venglovecz V., Imre Földesi, Zoltán Pető, Áron Somorácz, Katalin Borka, Doranda Perdomo, Gergely L.Lukacs, Mike A. Gray, Stefania Monterisi, Manuela Zaccolo, Matthias Sendler,Julia Mayerle, Jens-Peter Kühn, Markus M. Lerch, Miklós Sahin-Tóth, Péter Hegyi. Alcohol Disrupts Levels and Function of the Cystic Fibrosis Transmembrane Conductance Regulator to Promote Development of Pancreatitis, Gastroenterology, (2014), Accepted (GASTRO-D14-00547R1) [IF: 13.926]

III. Kemény LV, Hegyi P, Rakonczay Z Jr, Borka K, Korompay A, Gray MA, Argent BE, Venglovecz V. Substance P inhibits pancreatic ductal bicarbonate secretion via neurokinin receptors 2 and 3 in the guinea pig exocrine pancreas. Pancreas. 40(5):793-5. (2011) [IF: 2.386] 


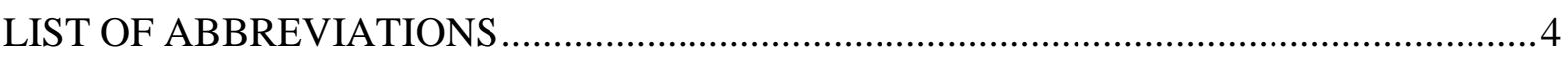

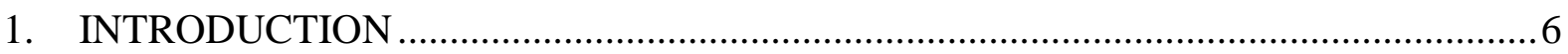

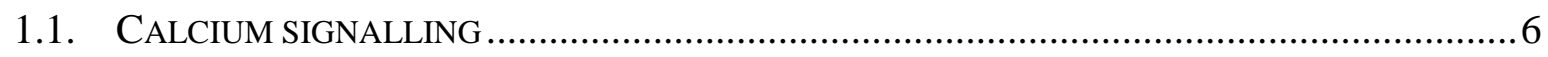

1.2. GASTRIC MYOFIBROBLASTS AND CALCIUM SIGNALLING.............................................

1.3. CALCIUM SIGNALING IN PANCREATIC DUCTAL EPITHELIAL CELLS (PDEC) ................... 8

1.4. REGULATION OF PANCREATIC BICARBONATE SECRETION .............................................

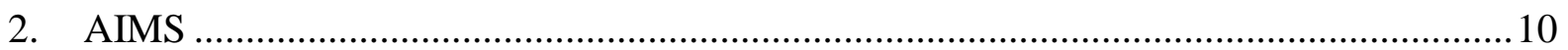

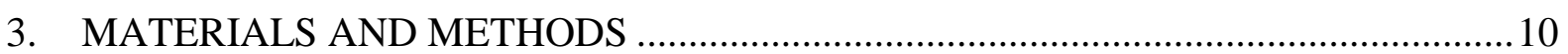

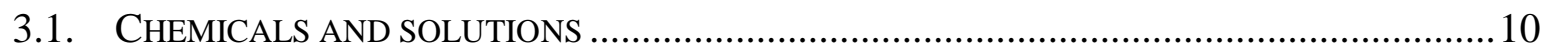

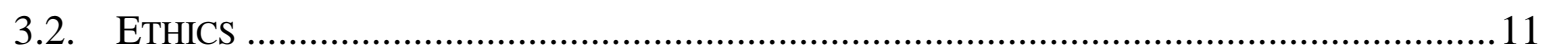

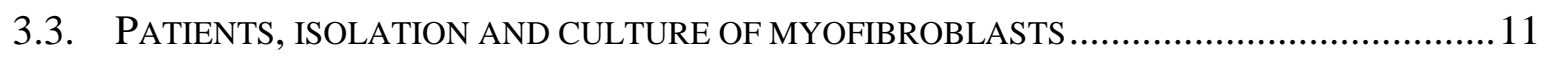

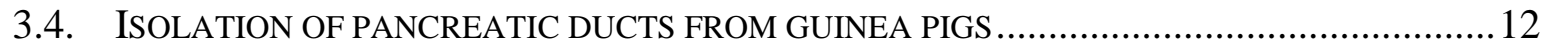

3.5. IMMUNOCYTOCHEMISTRY AND IMMUNHISTOCHEMISTRY ....................................... 13

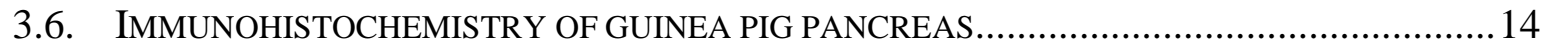

3.7. MEASUREMENT OF INTRACELlULAR $\mathrm{CA}^{2+}$ AND NA $^{+}$CONCENTRATIONS IN HGMS ...... 14

3.8. MEASUREMENTS OF INTRACELLULAR CALCIUM LEVELS IN CAPAN-1CELLS ................. 15

3.9. MEASUREMENT OF INTRACELLULAR PH IN ISOLATED PANCREATIC DUCTS................... 15

3.10. MEASUREMENT OF $\mathrm{HCO}_{3}{ }^{-}$SECRETION OF PANCREATIC DUCTS .................................... 16

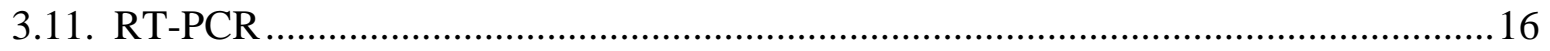

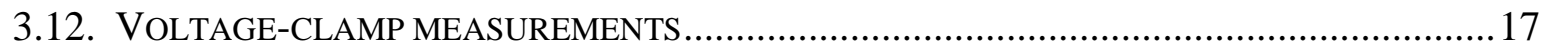

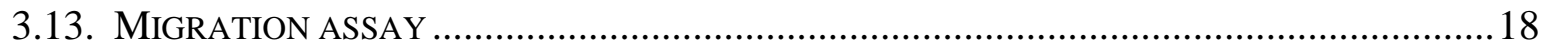

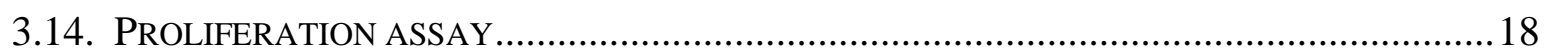

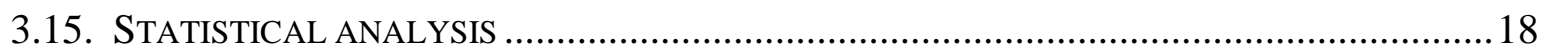

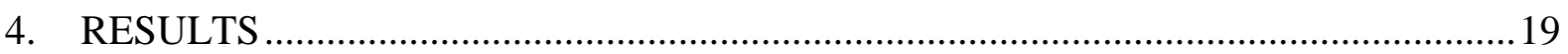

4.1. $\mathrm{NA}^{+} / \mathrm{CA}^{2+}$ EXCHANGERS REGULATE THE MIGRATION AND PROLIFERATION OF HUMAN

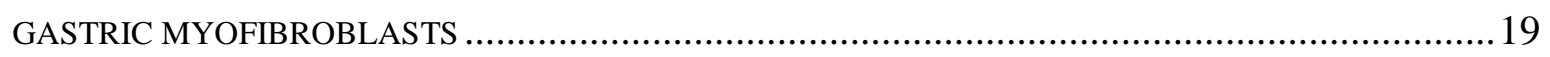

4.1.1. IMMUNOCYTOCHEMICAL IDENTIFICATION OF CELL CULTURES ........................... 19

4.1.2. SPONTANEOUS $\mathrm{CA}^{2+}$ OSCILLATION IN MYOFIBROBLAST ..................................... 19

4.1.3. HGMS ARE POSITIVE FOR CD117 AND PDGF-R, BUT NEGATIVE FOR DOG1 .....22 
4.1.4. INTRACELLULAR $\mathrm{CA}^{2+}$ OSCILLATIONS ARE DEPENDENT ON THE EXTRACELLULAR $\mathrm{NA}^{+} \mathrm{AND} \mathrm{CA}^{2+}$

4.1.5. INTRACELLULAR SODIUM ALSO DEPENDS ON EXTRACELLULAR SODIUM AND CALCIUM..

4.1.6. EFFECT OF DIFFERENT $\mathrm{CA}^{2+}$-TRANSPORT INHIBITORS ON THE INTRACELLULAR $\mathrm{CA}^{2+}$ AND NA $^{+}$LEVELS OF HGMS .26

4.1.7. MRNA AND PROTEIN EXPRESSION OF NCX IN HGMS ....................................26

4.1.8. MEASURING NA ${ }^{+} / \mathrm{CA}^{2+}$ EXCHANGER CURRENT ..................................................2

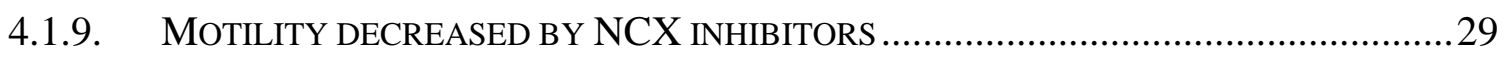

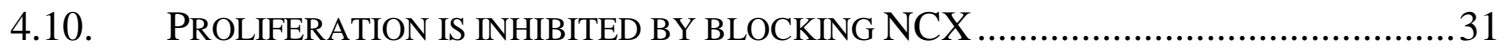

4.2. POA INCREASES INTRACELLULAR CALCIUM LEVELS IN PDEC ................................... 32

4.2.1. POA DEPLETES ER $\mathrm{CA}^{2+}$ STORES OF CAPAN-1 PANCREATIC DUCTAL CELLS ........ 32

4.2.2. POA DECREASES PMCA ACTIVITY IN CAPAN-1 CELLS ......................................33

4.3. SP INHIBITS PANCREATIC DUCTAL BICARBONATE SECRETION VIA NK2 AND NK3 RECEPTORS IN GUINEA PIG EXOCRINE PANCREAS

4.3.1. NK2 AND NK3 RECEPTORS ARE EXPRESSED ON THE LATERAL AND LUMINAL MEMBRANES OF INTRA/INTERLOBULAR DUCTS

4.3.2. INHIBITORY EFFECT OF SP ON PANCREATIC DUCTAL BICARBONATE SECRETION IS

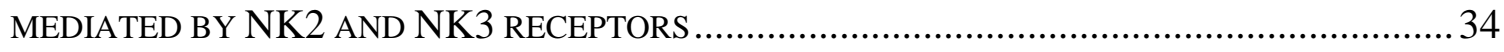

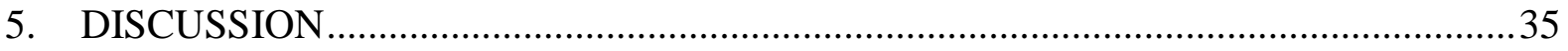

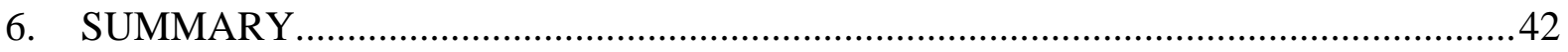

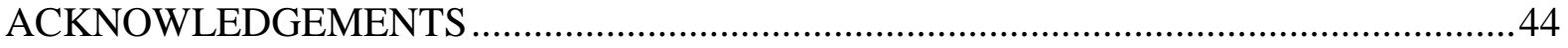

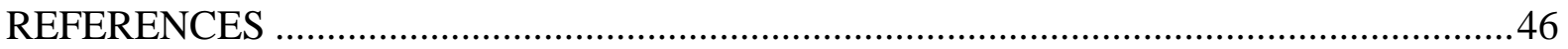

ANNEX 


\section{List of abbreviations}

$\left[\mathrm{Ca}^{2+}\right]_{\mathrm{i}} \quad$ Intracellular calcium

$\left[\mathrm{Na}^{+}\right]_{\mathrm{i}} \quad$ Intracellular sodium

$[\mathrm{ATP}]_{\mathrm{i}} \quad$ Intracellular adenosine triphosphate

$\mathrm{pH}_{\mathrm{i}} \quad$ Intracellular $\mathrm{pH}$

$\alpha$-SMA $\quad \alpha$-smooth-muscle-actin

AMV Avian myeloblastosis virus

AMV-RT Avian myeloblastosis virus reverse transcriptase

AP

Acute Pancreatitis

ATP

Adenosine triphosphate

$\mathrm{BCECF}$

2',7'-bis (2-carboxyethyl),5 (and -6) carboxyfluorescein

CB-DMB

3-amino-6-chloro-5-[(4-chloro-benzyl)amino]-N-[[(2,4-

dimethylbenzyl)amino]iminomethyl]-pyrazine-carboxamide

CFTR Cystic fibrosis transmembrane conductance regulator

DAPI 4,6-Diamidino-2-phenylindole

DEPC Diethyl dicarbonate

DMEM Dulbecco's Modified Eagle's Medium

DMSO Dimethyl sulfoxide

dNTP Deoxyribonucleotide-triphosphate

EDTA Ethylenediamine tetra-acetic acid

EGTA Ethylene glycol tetra-acetic acid

EdU 5-Ethynyl-2-deoxyuridine

ER Endoplasmic Reticulum

FITC Fluorescein isothiocyanate

FURA-2AM Acetoxymethyl-2-[5-[bis[(acetoxymethoxy-oxo-methyl)methyl]amino]-

4-[2-[2-[bis[(acetoxymethoxy-oxo-methyl)methyl]amino]-5-methylphenoxy]ethoxy]benzofuran-2-yl]oxazole-5-carboxylate

HEPES 4-(2-Hydroxyethyl)-1-piperazineethanesulfonic acid

HGM Human gastric myofibroblast

IGF-II Insulin-like growth factor II

$\mathrm{IP}_{3} \mathrm{R} \quad$ Inositol 1,4,5-triphosphate receptor

NCX Sodium-calcium exchanger

NK Neurokinin

PBS Phosphate buffered saline 
PDEC Pancreatic ductal epithelial cells

PDGFR Platelet-derived growth factor receptor

PMCA Plasma membrane $\mathrm{Ca}^{2+}$-ATPase

POA Palmitoleic acid

RPMI Roswell Park Memorial Institute

RT-PCR Reverse transcription polymerase chain reaction

RyR Ryanodine receptor

SBFI-AM Sodium-binding benzofuran isophthalate-acetoxymethyl-ester

SEM Standard error of mean

SERCA Sarcoplasmic/endoplasmic reticulum calcium ATPase

SOCE Store-operated calcium enty

SP Substance P

TBE Tris-buffered EDTA

$\mathrm{Tg} \quad$ Thapsigargin

TGF- $\beta 1 \quad$ Transforming growth factor beta 1 


\section{Introduction}

\subsection{Calcium signalling}

Calcium signalling is an important second messenger that has role in signal transduction in response to extracellular signals and a regulatory role in several intracellular processes ${ }^{1}$. Therefore, regulating intracellular calcium levels is still an important field of research, as there is still a lot to learn what mechanisms cells use to modulate intracellular calcium levels.

Calcium concentration is modulated by several different ion channels and transporters ${ }^{2}$. These ion channels and transporters work together to maintain calcium homeostasis of the cells. Calcium levels can be elevated by importing extracellular calcium into the cells, by releasing calcium from intracellular calcium stores or by inhibiting calcium removal mechanisms of the cells. On the other hand, calcium levels can be decreased by inhibiting calcium entry mechanisms and by promoting calcium removal mechanisms, like calcium ATP-ases.

However, different cell types express and use different sets of ion channels and transporters, according to their physiological role. For example intracellular calcium is crucial for cardiomyocites, smooth muscle cells and the interstitial cells of Cajal for contractions ${ }^{3,4}$, while astrocytic calcium signalling is regulating vascular tones and functional hyperaemia ${ }^{5}$. Besides its physiological role in several cells, toxic calcium signals have an important role in pathophysiological conditions as well. Our group has showed that ethanol and bile acids induce calcium signalling in pancreatic duct and colon cells, which might contribute to the pathogenesis of acute pancreatitis and to the development of diarrhoea ${ }^{6,7}$.

However, there are other regulatory systems that do not utilize calcium signalling. Our group has shown that Substance P inhibits bicarbonate secretion of pancreatic ducts via a protein kinase $\mathrm{C}$ mediated pathway, thus regulating bicarbonate secretion in a calcium independent way $^{8}$.

Nevertheless, understanding more about the regulation of calcium homeostasis might offer a potential therapeutic benefit in certain diseases. Therefore, it is essential to learn more about the calcium homeostasis in different cell types of the gastrointestinal tract. 


\subsection{Gastric myofibroblasts and calcium signalling}

Myofibroblasts are contractile, non-excitable, transitional cells between fibrocytes and smooth muscle cells ${ }^{9}$. Myofibroblasts transform from tissue fibroblasts by transforming growth factor beta 1 (TGF- $\beta 1$ ) and are localized to the subepithelium throughout the whole gastrointestinal tract ${ }^{10}$. They are crucial for the production of extracellular matrix, for morphogenesis, they also take part in the inflammatory process related to tissue repair and secrete a broad spectrum of bioactive molecules altering the microenvironment around epithelial cells in response to different noxa ${ }^{11,12}$. It has been shown in mice and rats that fibroblasts contribute to gastric and oesophageal ulcer healing ${ }^{13-15}$. Their involvement in the regeneration of the gastric mucosa after ethanol-induced gastric damage has also been shown in rats ${ }^{16}$.

Besides their physiological roles, in pathophysiological conditions myofibroblasts contribute to chronic gastritis and to tumor development of gastric cancer too ${ }^{17,18}$. Moreover, cancerassociated myofibroblasts reside in the tumor mass after the malignant transformation and promote the angio-neogenesis and metastasis formation of the malignant cells ${ }^{19}$. There is evidence now that these cells may originate at least partly from bone marrow from mesenchymal stem cells and they contribute to the formation of mesenchymal stem cell niche and promote tumor growth in mouse ${ }^{20}$. A further relevance of HGMs is that they might serve as a predictive factor of the outcome of gastric cancer: high tumor TGF- $\beta 1$ activity levels in tumor-derived myofibroblasts significantly corralated with worse survival in gastric cancer patients $^{21}$.

Intracellular free $\mathrm{Ca}^{2+}$ concentration $\left(\left[\mathrm{Ca}^{2+}\right]_{\mathrm{i}}\right)$ is a signal important cellular processes, like motility and cell division, which determine the behavior of a cell in a particular environment ${ }^{22}$. There are a number of pathways by which $\left[\mathrm{Ca}^{2+}\right]_{\mathrm{i}}$ is modulated according to the needs of cell function ${ }^{23}$. Mainly, $\mathrm{Ca}^{2+}$ can enter the cell from the extracellular space into the cytosol via non-specific cation channels, voltage-sensitive $\mathrm{Ca}^{2+}$ channels and sodiumcalcium exchangers (NCXs). It is known that NCX plays an important role in regulating the $\left[\mathrm{Ca}^{2+}\right]_{\mathrm{i}}$, in several cell types ${ }^{24}$. NCX alters the migration of rat tendon fibroblasts, and migration and proliferation in human pulmonary artery smooth muscle cells ${ }^{25,26}$. Moreover, it has been reported that $\mathrm{Ca}^{2+}$-entry-mode operation of NCX is required for des-Arg10-kallidin- 
and TGF $\beta 1$-stimulated fibrogenesis and participates in the maintenance of the myofibroblast phenotype $\mathrm{p}^{27}$.

The plasma membrane protein NCX is a ubiquitously expressed protein with three isoforms, which all can function in forward - also known as $\mathrm{Ca}^{2+}$-exit - mode, or in reverse $-\mathrm{Ca}^{2+}$ entry - mode ${ }^{28,29}$, depending on the membrane potential and the chemical gradient of $\mathrm{Na}^{+}$and $\mathrm{Ca}^{2+}$.

As there is not enough information how human myofibroblasts regulate $\left[\mathrm{Ca}^{2+}\right]_{\mathrm{i}}$, we set out to characterize the calcium homeostasis of human gastrointestinal myofibroblasts, focusing on human gastric myofibroblasts (HGMs) and on NCX, and to investigate the relationship between NCX and cell function, such as migration and proliferation.

\subsection{Calcium signaling in pancreatic ductal epithelial cells (PDEC)}

Calcium is an important signaling molecule in the fluid and $\mathrm{HCO}_{3}{ }^{-}$secretion of pancreatic ductal epithelium. Calcium regulates $\mathrm{HCO}_{3}{ }^{-}$secretion by promoting ATP production, but also activates calmodulin, which is involved in several cellular processes in PDEC $^{30}$. Although physiological $\mathrm{Ca}^{2+}$ signaling has many beneficial effects in PDEC, which help to promote $\mathrm{HCO}_{3}{ }^{-}$secretion, recent studies suggest that some of the pathogenic factors for acute pancreatitis (bile acids, trypsin) induce sustained elevation in $\left[\mathrm{Ca}^{2+}\right]_{\mathrm{i}}$. Therefore, it is essential to understand the mechanisms underlying the pathophysiological elevation of $\left[\mathrm{Ca}^{2+}\right]_{\mathrm{i}}$.

Despite the high incidence and high rate of mortality of AP, there is no specific therapy specifically targeting the disease ${ }^{31}$. Excessive alcohol consumption is present in the history of many acute and chronic pancreatitis patients ${ }^{32-34}$, suggesting the role of ethanol and ethanol metabolites in the disease pathogenesis. However, most of the studies investigating the role of ethanol and its' metabolites focused on pancreatic acinar or stellate cells ${ }^{35-37}$. There is evidence, that not only acinar and stellate cells, but pancreatic ductal cells also play an important role in the pathogenesis of pancreatitis ${ }^{38,39}$. Furthermore, we have shown that palmitoleic acid (POA), a known non-oxidative metabolite of ethanol, induces calcium elevation in PDEC cells. Additional experiments confirmed that ethanol and POA inhibits fluid secretion of PDEC cells via modulating $\left[\mathrm{Ca}^{2+}\right]_{\mathrm{i}}$, causing mitochondrial injury and altering the intracellular ATP levels. As sustained $\left[\mathrm{Ca}^{2+}\right]_{\mathrm{i}}$ elevation causes mitochondrial $\mathrm{Ca}^{2+}$ overload $^{40}$, which impairs mitochondrial membrane potential and ATP production ${ }^{41,42}$, our goal was to identify the mechanisms that maintain the elevated $\left[\mathrm{Ca}^{2+}\right]_{\mathrm{I}}$ following POA treatment in PDEC. 


\subsection{Regulation of pancreatic bicarbonate secretion}

The exocrine pancreas secretes $1-2 \mathrm{~L}$ pancreatic juice a day ${ }^{43}$. The pancreatic ductal epithelial cells (PDEC) contribute to the juice production by secreting a $\mathrm{HCO}_{3}{ }^{-}$rich fluid ${ }^{38}$. The $\mathrm{HCO}_{3}{ }^{-}$ rich alkaline pancreatic fluid, in response to meal, washes the digestive enzymes out of the pancreatic ductal tree and neutralizes the acidic chyme entering the duodenum.

The regulation of pancreatic ductal secretion is a very complex system controlled by multiple stimulatory and inhibitory neural and hormonal mechanisms.

The peptide hormone secretin, which is released by duodenal enteroendocrine cells in response to acidic chyme, is generally considered as the most important regulator of pancreatic fluid and $\mathrm{HCO}_{3}{ }^{-}$secretion ${ }^{44}$. Secretin activates the cystic fibrosis transmembrane conductance regulator (CFTR) by elevating cAMP levels and activating protein kinase $\mathrm{A}$ in PDEC. Vasoactive intestinal peptide and $\beta$ adrenerg agonists stimulate secretion in a similar cAMP mediated way.

Although the stimulatory pathways of pancreatic juice secretion are well known, the inhibitory control of fluid and $\mathrm{HCO}_{3}{ }^{-}$secretion has not been fully characterized. It has been shown that some molecules can indirectly (methionine encapheline, somatostatin, insulin, peptide YY) or directly (arginine vasopressin, 5-hydroxytryptamine, ATP and epidermal growth factor) inhibit pancreatic ductal secretion ${ }^{45}$. Moreover, previous work of the lab revealed that in the pancreas, SP directly inhibits basal and secretin-stimulated ductal fluid secretion $^{45,46}$. Substance P (SP) a well-known neuropeptide, which plays an essential role in numerous physiological processes. Recently, we have shown that the inhibitory effect of SP can be partially reversed by spantide, a nonselective neurokinin (NK) receptor antagonist in the guinea pig pancreas ${ }^{47}$, indicating that NK receptors are involved in the inhibitory effect of SP. Furthermore, it has been shown that the inhibition of SP is calcium independent and mediated by protein kinase $\mathrm{C}$, however it is not know which NK receptor subtype is involved in the regulation of ductal secretion ${ }^{8}$. SP is known to exert its effects via 3 distinct mammalian NK receptors subtypes, NK1, NK2, and $\mathrm{NK} 3^{48}$. Therefore, we set out to characterize the role of $\mathrm{NK}$ receptor subtypes in the regulation of pancreatic ductal bicarbonate secretion. 


\section{Aims}

The main aims of this work were to investigate the role of calcium in the physiology of HGMs and pathophysiology of PDEC and to further characterize the calcium independent neuroendocrine regulation of ion transporters in pancreatic ductal secretion.

Our specific aims were:

1. To identify the ion transporter(s) involved in the regulation of the calcium homeostasis of HGMs and to investigate the role of the(se) ion transporter(s) in the migration and proliferation of HGMs.

2. To identify calium transport mechanisms involved in the POA induced sustained elevation of $\left[\mathrm{Ca}^{2+}\right]_{\mathrm{i}}$ in PDEC.

3. To investigate the expression of NK receptor subtypes in the guinea pig pancreas and to identify which subtype(s) mediate(s) the effect of SP on secretin-stimulated bicarbonate secretion.

\section{Materials and Methods}

\subsection{Chemicals and solutions}

Chemicals and solutions used for cell culture were purchased from Sigma-Aldrich (Budapest, Hungary). All reagents for immunocytochemistry were purchased from Jackson Immunoresearch (Stanford, CA, USA). The mouse anti-NCX3 antibody was a kind gift from Dr. Michela Ottolia (Cedars-Sinai, Los Angeles, CA, USA).

All secondary antibodies, the Target Retrieval Solution and the Fluoromount medium were purchased from Dako, Glostrup, Denmark. Vectashield mounting medium was from Vector Laboratories, Peterborough, UK.

Polyclonal CD117 (Labvision, Fremont, USA), DOG1 (clone SP31, Labvision), PDGFR $\alpha$ (epitop specific clone, Labvision) and ki67 (clone B56, Histopathology Ltd., Pécs, Hungary) were used used in the immuncytochemistry and human immunhistrochemistry experiments. RP67580, MEN10376, and SB218795 (which are selective antagonists of NK1, NK2, and NK3 receptors, respectively) were purchased from Tocris Biosciences (Bristol, UK) and were used to study the inhibitory effect of SP. 
Neurokinin 1 receptor primary antibody was obtained from Thermo Fisher Scientific (Budapest, Hungary; diluted 1:100), NK2 and NK3 receptor antibodies were from Abcam (Cambridge, UK; diluted 1:100).

Palmitoleic acid (POA) was obtained from Cayman-Chemicals (Ann Arbor, MI, USA), Gd ${ }^{3+}$, Substance P and secretin from Sigma-Aldrich (Budapest, Hungary), Thapsigargin from Tocris Biosciences (Bristol, UK).

Chemicals and reagents for PCR techniques, were purchased from Promega (Southampton, UK), unless indicated otherwise. All primers were purchased from Bio Basic (Markham, Canada).

The solvent of acetoxymethyl 2-[5-[bis[(acetoxymethoxy-oxo-methyl)methyl]amino]-4-[2[2-[bis[(acetoxymethoxy-oxo-methyl)methyl]amino]-5-methyl-phenoxy]ethoxy]benzofuran2-yl]oxazole-5-carboxylate (FURA2-AM, Invitrogen, Paisley, UK), for sodium-binding benzofuran isophthalate-AM (SBFI-AM, Invitrogen, Paisley, UK) dyes, for $\mathrm{pH}$ sensitive BCECF (Invitrogen, Paisley, UK) and for the NCX inhibitor 3-amino-6-chloro-5-[(4-chlorobenzyl)amino]-N-[[(2,4-dimethylbenzyl)amino]iminomethyl]-pyrazine-carboxamide $\quad$ (CBDMB, Sigma-Aldrich, Budapest, Hungary) was dimethyl sulfoxide (DMSO) with pluronic acid (Biotinum, Inc. CA, USA) in a ratio of 1:1. The final concentration of DMSO was always below $1 \%$.

\subsection{Ethics}

The study was approved by the Ethics Committee of the University of Szeged (Szeged, Hungary). All patients gave informed consent.

\subsection{Patients, isolation and culture of myofibroblasts}

Three specimens were obtained from patients undergoing gastric tumor resection surgery in the Department of Surgery, University of Szeged, Hungary. Specimens were dissected postoperatively at least $4-10 \mathrm{~cm}$ away from the visible tumor border and were transported immediately to laboratory on ice cold media. Two other gastric specimens from multiple organ cadaver donors were also obtained following donor surgery and cultured similarly. Additionally, we isolated pancreatic myofibroblasts from a patient with chronic pancreatitis, and oesophageal, duodenal and colonic myofibroblasts from two organ cadaver donors. The details of patients can be found in Table 1. The isolation of myofibroblasts was performed using a previously described method ${ }^{49}$. Briefly, the specimens were washed and chopped into 
approximately $1-2 \mathrm{~mm}^{3}$ pieces and were then bathed in a shaking water bath at $37{ }^{\circ} \mathrm{C}$ for 15 min with $1 \mathrm{mM}$ dithiothreitol. After washing, the chopped pieces were incubated for $30 \mathrm{~min}$ at $37{ }^{\circ} \mathrm{C}$ with $1 \mathrm{mM}$ ethylenediamine tetra-acetic acid (EDTA) four times. Samples were cultured for 1 to 2 weeks in Roswell Park Memorial Institute (RPMI) medium supplemented with $10 \%$ fetal bovine serum, $1 \%$ penicillin-streptomycin and $2 \%$ antibiotic-antimycotic solution. After the cells became confluent, they were trypsinized with $0.25 \%$ trypsin-EDTA and were transferred into Dulbecco's Modified Eagle's Medium (DMEM) complemented with $4 \mathrm{mM}$ L-glutamine containing $10 \%$ fetal bovine serum, $1 \% \mathrm{v} / \mathrm{v}$ amino acid solution, $1 \% \mathrm{v} / \mathrm{v}$ penicillin-streptomycin and $2 \% \mathrm{v} / \mathrm{v}$ antibiotic-antimycotic solution. Medium was replaced every $48 \mathrm{~h}$ and cells were passaged at full confluency up to passage 10. Cultures were continually incubated at $37{ }^{\circ} \mathrm{C}$ in an incubator gassed with a mixture of $5 \% \mathrm{CO}_{2}$ and 95 $\%$ air. All cultures were handled separately. Experiments were performed on different preparations from different patients, the samples were never combined. $\mathrm{N}$ numbers are given in the text and in the legends as follows: number of independent experiments / number of cells per experiment, unless indicated otherwise.

\begin{tabular}{c|c|c|l}
\hline Patient no. & Gender & Age & \multicolumn{1}{c}{ Source of myofibroblast } \\
\hline 1 & Male & 72 & Adjacent normal tissue next to gastric cancer \\
2 & Female & 85 & Adjacent normal tissue next to gastric cancer \\
3 & Female & 59 & Adjacent normal tissue next to gastric cancer \\
4 & Male & 45 & Transplantological gastric biopsy from cadaver donor \\
5 & Female & 52 & Transplantological gastric biopsy from cadaver donor \\
6 & Male & 60 & Transplantological duodenal biopsy from cadaver donor \\
7 & Male & 45 & Pancreas resection from chronic pancreatitis patient \\
8 & Male & 33 & Transplantological oesophagus and colon biopsy from cadaver donor \\
\hline
\end{tabular}

\subsection{Isolation of pancreatic ducts from guinea pigs}

4-8 week-old guinea pigs were sacrificed by cervical dislocation. Intra/interlobular ducts were isolated by enzymatic digestion and microdissection from the pancreas. Isolated ducts were cultured overnight as previously described ${ }^{50}$. 


\subsection{Immunocytochemistry and immunhistochemistry}

14000 HGMs per chamber were seeded onto chamber slides and were allowed to recover overnight. To fix cells $3.6 \%$ paraformaldehyde was used for $30 \mathrm{~min}$ and washed three times with phosphate buffered saline (PBS, Invitrogen, Paisley, UK). Permeabilization was performed by incubation for 30 min using a filtered, PBS-based solution containing $0.2 \%$ Triton X-100 and $0.3 \%$ protease-free bovine serum albumin. Cells were then incubated with $10 \%$ donkey serum in PBS for $30 \mathrm{~min}$. After washing three times with PBS, primary antibodies were added to the chambers and slides were incubated overnight in moist atmosphere at $4{ }^{\circ} \mathrm{C}$. The following primary antibodies were used: anti- $\alpha$-SMA antibody raised in guinea pig (1:100), anti-vimentin antibody raised in mouse (1:400), anti-cytokeratin antibody raised in mouse (Dako, Glostrup, Denmark), anti-NCX1, -NCX2 raised in goat (1:50, Santa Cruz Biotechnology, Santa Cruz, CA, USA), anti-NCX3 and anti-ki67 in mouse. Primary antibodies were removed by sequence washes for 10 min each with $0.14 \mathrm{M} \mathrm{NaCl}$, $0.5 \mathrm{M} \mathrm{NaCl}, 0.14 \mathrm{M} \mathrm{NaCl}$ dissolved in PBS, respectively. HGMs were incubated with secondary antibodies for $60 \mathrm{~min}$ in dark and moist conditions. Fluorescein isothiocyanate FITC-conjugated anti-guinea pig secondary antibody (1:400), Texas Red conjugated antimouse antibody (1:400), FITC-conjugated anti-goat and anti-mouse secondary antibodies (1:400) were used as secondary antibodies. After hybridization, slides were washed three times with PBS and covered with Vectashield mounting medium containing 4,6-diaminido-2phenylindole (DAPI) for nuclear stanining and were cover-slipped.

Control samples for PDGFRa, DOG1 and CD117 stainings were obtained from gastrointestinal stromal tumor together with peritumoral normal small bowel. Tissues were fixed in $4 \%$ buffered formaldehyde, embedded into paraffin, then $4 \mu \mathrm{m}$-thick sections were cut onto silanized slides. Deparaffinization and antigen retrieval of sections were made in Target Retrieval Solution pH 6 for PDGFR $\alpha$ and $\mathrm{pH} 9$ for CD117 and DOG1. For nonspecific antigen blocking 1\% BSA-TBS and goat serum were used in a dilution of 1:100. Primary antibodies of CD117, DOG1 and PDGFR $\alpha$ were applied in a dilution of 1:200, 1:100 and 1:80, respectively. The secondary FITC anti-mouse antibody was used in a dilution of 1:400. Nuclear counterstaining was performed by DAPI in a dilution of 1:100. Sections were coverslipped by Fluoromount medium. 


\subsection{Immunohistochemistry of guinea pig pancreas}

Immunohistochemical analysis of NK receptor expressions was performed on $4 \%$ buffered formalin-fixed sections of guinea pig pancreas embedded in paraffin. After deparaffination with EZ Prep Concentrate 10X (Ventana Medical Systems, Tucson, AZ), endogen peroxidase blocking and antigen retrieval (CC1, Ventana Medical Systems, Tucson, AZ)

Neurokinin 1 receptor primary antibody was diluted 1:100, NK2 and NK3 receptor antibodies were diluted 1:100. Sections were incubated with primary antibodies at at $42^{\circ} \mathrm{C}$ for $30 \mathrm{~min}$. Immunohistochemical stainings were carried out with HRP multimer based, biotin-free detection technique according to the protocol of automated Ventana system (Ventana Benchmark XT automate, Ventana Medical Systems, Tucson, AZ). UltraView ${ }^{\mathrm{TM}}$ Universal DAB Detection Kit (Ventana Medical Systems, Tucson, AZ) was used for visualisation.

\subsection{Measurement of intracellular $\mathrm{Ca}^{2+}$ and $\mathrm{Na}^{+}$concentrations in HGMs}

HGMs (5 000, 30000 or 100000 cells) were seeded onto a coverslip and were allowed to recover overnight. Then the coverslip was mounted on an inverted fluorescent light microscope (Olympus, Budapest, Hungary). The cells were bathed in standard HEPES solution at $37{ }^{\circ} \mathrm{C}$ and were loaded with the $\mathrm{Ca}^{2+}$-sensitive fluorescent dye FURA2-AM $(5 \mu \mathrm{M})$ for $60 \mathrm{~min}$. After loading, the cells were continuously perfused with solutions at a rate of 6 $\mathrm{ml} / \mathrm{min}$. Changes in $\left[\mathrm{Ca}^{2+}\right]_{\mathrm{i}}$ were measured using an imaging system (Cell R; Olympus). HGMs as regions of interests were excited with light at wavelengths of $340 \mathrm{~nm}$ and $380 \mathrm{~nm}$, and the 340/380 fluorescence emission ratio (F340/F380) was measured at $510 \mathrm{~nm}$. For intracellular $\mathrm{Na}^{+}$concentration $\left(\left[\mathrm{Na}^{+}\right]_{\mathrm{i}}\right)$ measurements HGMs (100 000 cells) were handled the same way as for the $\mathrm{Ca}^{2+}$ measurements. The cells were bathed in standard HEPES solution at $37^{\circ} \mathrm{C}$ and loaded with the $\mathrm{Na}^{+}$-sensitive fluorescent dye SBFI-AM $(5 \mu \mathrm{M})$ for 50 min. For $\left[\mathrm{Na}^{+}\right]_{\mathrm{i}}$ measurements the same filters were used as for FURA2-AM and the F340/F380 ratio was measured at 510nm. When excited at $340 \mathrm{~nm}$, the calcium indicator FURA2-AM and the $\mathrm{Na}^{+}$indicator SBFI-AM dyes are sensitive to the intracellular $\mathrm{Ca}^{2+}$ and $\mathrm{Na}^{+}$concentrations, respectively, but insensitive to these ions when excited at $380 \mathrm{~nm}$, thus corresponds to the dye concentration only. Therefore, measuring the F340/F380 ratio is more sensitive, then F340 alone, as not only the change in F340 corresponds the intracellular ion concentrations, but the inverse change in F380 as well, as the concentration of the dye changes too. One measurement was obtained per second. Compositions of solutions are detailed in Table 2. 


\begin{tabular}{|c|c|c|c|c|c|c|}
\hline & HEPES & $\begin{array}{l}\mathrm{Na}^{+} \text {-free } \\
\text { HEPES }\end{array}$ & $\begin{array}{l}\mathrm{Ca}^{2+} \text {-free } \\
\text { HEPES }\end{array}$ & $\begin{array}{l}\mathrm{Na}^{+} / \mathrm{Ca}^{2+} \text {-free } \\
\text { HEPES }\end{array}$ & $\begin{array}{l}K^{+} \text {-free } \\
\text { HEPES }\end{array}$ & $\begin{array}{c}\mathrm{Na}^{+} / \mathrm{Ca}^{2+} / \mathrm{K}^{+} \text {-free } \\
\text { HEPES }\end{array}$ \\
\hline $\mathrm{NaCl}$ & 130 & $\mathbf{0}$ & 132 & $\mathbf{0}$ & 135 & $\mathbf{0}$ \\
\hline $\mathrm{KCl}$ & 5 & 5 & 5 & 5 & 0 & $\mathbf{0}$ \\
\hline Na-HEPES & 10 & 0 & 10 & 0 & 10 & $\mathbf{0}$ \\
\hline $\mathrm{CaCl}_{2}$ & 1 & 1 & $\mathbf{0}$ & $\mathbf{0}$ & 1 & $\mathbf{0}$ \\
\hline $\mathrm{MgCl}_{2}$ & 1 & 1 & 1 & 1 & 1 & 1 \\
\hline Glucose & 10 & 10 & 10 & 10 & 10 & 10 \\
\hline NMDG & 0 & 140 & 0 & 144 & 0 & 154 \\
\hline HEPES & $\mathbf{0}$ & 10 & $\mathbf{0}$ & 10 & 0 & $\mathbf{0}$ \\
\hline EGTA & $\mathbf{0}$ & $\mathbf{0}$ & 1 & 1 & 0 & 1 \\
\hline
\end{tabular}

Table 2. Composition of solutions. Values are in millimolar.

\subsection{Measurements of intracellular calcium levels in Capan-1cells}

Capan-1 cells were obtained from the American Type Culture Collection (HTB-79, ATCC, Manassas, VA) and were used for experiments between 20-60 passages. Cells were cultured according to the distributors' instruction. For intracellular $\mathrm{Ca}^{2+}$ concentration $\left(\left[\mathrm{Ca}^{2+}\right]_{\mathrm{i}}\right)$ measurements 500.000 cells were seeded onto $24 \mathrm{~mm}$-diameter cover glasses. Then Capan-1 cells were incubated in standard HEPES solution and loaded with Fura2-AM (2.5 $\mu \mathrm{mol} / \mathrm{L})$ for $30 \mathrm{~min}$ at $37^{\circ} \mathrm{C}$. Cover glasses were then transferred to a perfusion chamber mounted on an IX71 inverted microscope (Olympus, Budapest, Hungary). The measurements were carried out as described above.

\subsection{Measurement of intracellular $\mathrm{pH}$ in isolated pancreatic ducts}

Changes in intracellular $\mathrm{pH}(\mathrm{pHi})$ were measured by microfluorimetry using the $\mathrm{pH}$-sensitive fluorescent dye 2',7'-bis (2-carboxyethyl),5 (and -6) carboxyfluorescein (BCECF) ${ }^{51}$. Briefly, ducts were bathed in standard HEPES solution at $37^{\circ} \mathrm{C}$ and loaded with $2 \mu \mathrm{mol} / \mathrm{l} \mathrm{BCECF}$ for 20-30 min. After loading the ducts, $\mathrm{pH}_{\mathrm{i}}$ was measured using a Cell ${ }^{\mathrm{R}}$ imaging system (Olympus, Budapest, Hungary). Ducts were excited with light at wavelength of 490 and $440 \mathrm{~nm}$, and the 490/440 fluorescence emission ratio was measured at $535 \mathrm{~nm}$ at a speed of one measurement per second. Calibration of fluorescence was performed using high $\mathrm{K}^{+}$nigericin technique. ${ }^{52,53}$ 


\subsection{Measurement of $\mathrm{HCO}_{3}^{-}$secretion of pancreatic ducts}

The rate of bicarbonate secretion was estimated by the alkali load technique. ${ }^{51,52}$. Briefly, $\mathrm{HCO}_{3}{ }^{-}$secretion is estimated by the rate of $\mathrm{pH}_{\mathrm{i}}$ recovery from an alkaline load. Ducts were exposed to $20 \mathrm{mM} \mathrm{NH}_{4} \mathrm{Cl}$ in $\mathrm{HCO}_{3}{ }^{-}$buffered solution, which produces an increase in $\mathrm{pH}_{\mathrm{i}}$ due to the influx of $\mathrm{NH}_{3}$ across the membrane. Our group has demonstrated that recovery of $\mathrm{pH}_{\mathrm{i}}$ under these conditions is due to $\mathrm{HCO}_{3}{ }^{-}$secretion of duct cells ${ }^{47}$. Therefore, the initial rate of recovery from alkalosis over the first $30 \mathrm{~s}$ from the highest $\mathrm{pH}_{\mathrm{i}}$ value obtained in the presence of $\mathrm{NH}_{4} \mathrm{Cl}$ was calculated, as described previously ${ }^{47}$.

\subsection{RT-PCR}

RNA was isolated from HGM cultures using Qiagen RNeasy Mini Kit (Qiagen House, Crawly, UK) according to the manufacturer's instructions. $3 \mu \mathrm{g}$ of RNA was reverse transcribed to cDNA. RNA/primer annealing was performed with $0.5 \mu \mathrm{g}$ oligo-dT primer at $65^{\circ} \mathrm{C}$ for $5 \mathrm{~min}$. After cooling, samples were reverse transcribed in a final reaction volume of $30 \mu$ containing the annealed RNA/primer set, 5x AMV (avian myeloblastosis virus) buffer, 1.25 mM dNTP (deoxyribonucleotide-triphosphates) mix, 20 unit human RNAse inhibitor, 15 unit AMV-RT (AMV-reverse transcriptase) and diethyl dicarbonate (DEPC)-treated water. Reactions were incubated at $42{ }^{\circ} \mathrm{C}$ for $60 \mathrm{~min}$; enzymes were inactivated at $85^{\circ} \mathrm{C}$ for $5 \mathrm{~min}$. $1 \mu \mathrm{l}$ of cDNA was used as template for each PCR in a final volume of $25 \mu 1$, containing master mix, 10x Taq-buffer, $10 \mathrm{nM}$ dNTPs per sample, 2.5 unit Taq-polymerase per sample, DEPC-treated water and $1 \mu \mathrm{M}$ NCX primer set. The sequences of NCX primers are detailed in Table 3. The expected PCR product sizes were 231, 243 and $154 \mathrm{bp}$ for NCX1, NCX2 and NCX3, respectively. The identities of the PCR products were confirmed by DNA sequencing (performed by Biocenter $2000 \mathrm{Kft}$., Szeged, Hungary). PCR settings were as follows: denaturation at $95{ }^{\circ} \mathrm{C}$ for $15 \mathrm{~s}$, annealing at $60{ }^{\circ} \mathrm{C}$ for $15 \mathrm{~s}$, extension at $72{ }^{\circ} \mathrm{C}$ for $45 \mathrm{~s}, 30$ cycles. PCR products and DNA HyperLadderPlus (BioLine, Taunton, USA) were run on a 2 $\%$ agarose gel containing $0.005 \%$ ethidium-bromide in Tris-buffered EDTA (TBE) buffer, then the gel was illuminated in a UV chamber and and photographs were taken with AlphaImager EC (Alpha Innotech Corporation, San Leandro, CA, USA). 


\begin{tabular}{ll}
\hline Primer name & Sequence (5'-3') \\
\hline NCX1 forward & TGTGCATCTCAGCAATGTCA \\
NCX1 reverse & TTTCCTCGAGCTCCAGATGT \\
NCX2 forward & CTGACGGTGTTCTGGAAGGT \\
NCX2 reverse & CTGAGATCCTACCCCACCAA \\
NCX3 forward & ACAAGCGGCTGCTCTTCTAC \\
NCX3 reverse & GCTTCTGCTTGAGGTCCTTG \\
\hline
\end{tabular}

Table 3. NCX primer sequences

\subsection{Voltage-clamp measurements}

Isolated HGMs were cultured as described above. For patch clamp experiments, the cells were trypsinised, then the cell suspension was centrifuged at $200 \mathrm{~g}$ for 5 minutes. Thereafter the cells were suspended in fresh DMEM and put into the setup chamber. HEPES buffered Tyrode's solution contained (in $\mathrm{mM} / \mathrm{l}$ ) $\mathrm{NaCl} 144, \mathrm{NaH}_{2} \mathrm{PO}_{4} 0.4, \mathrm{KCl} 4.0, \mathrm{CaCl}_{2} 1.8, \mathrm{MgSO}_{4}$ 0.53 , Glucose 5.5, and HEPES 5 at $\mathrm{pH}$ of 7.4. The $\mathrm{K}^{+}$-free solution contained (in $\mathrm{mM} / \mathrm{l}$ ) $\mathrm{NaCl}$ 135, $\mathrm{CsCl} \mathrm{10,} \mathrm{CaCl}_{2} 1, \mathrm{MgCl}_{2} 1, \mathrm{BaCl}_{2}$ 0.2, $\mathrm{NaH}_{2} \mathrm{PO}_{4}$ 0.33, Tetraethylammonium cloride 10, HEPES 10, Glucose $10 \mu \mathrm{M}$, Ouabain $20 \mu \mathrm{M}$, Nisoldipine $1 \mu \mathrm{M}$, Lidocaine $50 \mu \mathrm{M}$ at $\mathrm{pH}$ of 7.4, and the pipette solution for measuring NCX current was CsOH 140, Aspartic acid 75, TEACl 20, MgATP 5, HEPES 10, $\mathrm{NaCl}$ 20, Ethylene glycol tetraacetic acid (EGTA) 20, $\mathrm{CaCl}_{2} 7$ and the $\mathrm{pH}$ was adjusted to 7.2 with $\mathrm{CsOH}$. One drop of cell suspension was placed within a transparent recording chamber mounted on the stage of an inverted microscope (TMS, Nikon, Tokyo, Japan) and individual HGMs were allowed to settle and adhere to the chamber bottom for at least 30 minutes before superfusion was initiated and maintained by gravity. Ventricular myocytes were enzymatically digested from hearts of mongrel dogs as previously described ${ }^{54}$. HEPES buffered Tyrode's solution served as the normal superfusate. Micropipettes were fabricated from borosilicate glass capillaries using a P-97 Flaming/Brown micropipette puller (Sutter Co, Novato, CA, USA) and had a resistance of 2 - $5 \mathrm{M} \Omega$ when filled with pipette solution. The membrane currents were recorded with Axopatch-1D amplifier (Axon Instruments, Foster City, CA, USA) using the whole-cell configuration of the patch-clamp technique. After establishing high (1-10 G $\Omega$ ) resistance seals by gentle suction, the cell membrane beneath the tip of the electrode was disrupted by further suction or by applying $1.5 \mathrm{~V}$ electrical pulses for $1-5 \mathrm{~ms}$. The membrane currents were digitized using a $333 \mathrm{kHz}$ analog to digital converter (Digidata 1200, Axon Instruments) under software control (PCLAMP 6.0, Axon Instruments). The results were analyzed using software programs purchased from AXON (PCLAMP 6.0). Experiments were carried out at $37^{\circ} \mathrm{C}$. 


\subsection{Migration assay}

HGMs (routinely 125000 cells) were seeded onto six-well plates and were allowed to recover overnight in full media. On the following day, the HGM monolayer was gently scratched by a P2 tip in the middle of the well. Only wells containing even-sided and sharpedged wounds were used for experiments. After gentle washing for three times with serumfree media, an inverted light microscope was used to measure and photograph wounds. Reagents were then added to the wells in serum-free media and HGMs were incubated in $\mathrm{CO}_{2}$ incubator at $37{ }^{\circ} \mathrm{C}$ for $24 \mathrm{~h}$. Migration was evaluated by counting the cells in the same area of the wound after $24 \mathrm{~h}$ as reported earlier ${ }^{49}$.

\subsection{Proliferation assay}

Proliferation assays were performed as previously described (6). HGMs (routinely 50000 cells) were seeded onto cover glasses. After overnight recovery, they were synchronized by 30 hours of serum starvation, then $10 \mu \mathrm{M}$ Click-iT 5-ethynyl-2-deoxyuridine (EdU) [Alexa Fluor 488 Imaging Kit, Invitrogen, Oregon, US] was added to the cells for overnight incubation with or without treatment. After overnight incubation HGMs were fixed and permeabilized according to the manufacturer's protocol and to detect EdU incorporation. DAPI was used for nuclear staining. The proliferation rate was calculated by normalizing the number of EdU positive cells to the DAPI-stained cells in at least ten fields of 200x magnification per sample.

\subsection{Statistical analysis}

Values are shown as means \pm SEM. Statistical analyses were performed using non-parametric Kruskal-Wallis tests with post-hoc Wilcoxon tests for pairwise comparisons and Bonferroni correction to test post-hoc significance within groups. Simple pairwise comparisons were tested with Student's t test. $\mathrm{P}<0.05$ was accepted as significant. 


\section{Results}

\section{1. $\mathrm{Na}^{+} / \mathrm{Ca}^{2+}$ exchangers regulate the migration and proliferation of human gastric myofibroblasts}

\subsubsection{Immunocytochemical identification of cell cultures}

To identify myofibroblasts from different gastrointestinal tissues (pancreas, oesophagus, stomach, duodenum, colon), cultured cells were subjected to immunocytochemical analysis using antibodies to vimentin and $\alpha$-smooth-muscle actin ( $\alpha$-SMA) as specific markers of myofibroblasts. Cytokeratin and desmin antibodies were used for detecting epithelial and muscle cells, respectively. $\alpha$-SMA and vimentin verified the presence of myofibroblasts (Fig. 1), whereas desmin and cytokeratin negativity proved that no epithelial or smooth muscle cells were isolated. Purity of the myofibroblast cell cultures was $100 \%$.

\subsubsection{Spontaneous $\mathrm{Ca}^{2+}$ oscillation in myofibroblast}

Interestingly, depending on the source of isolation about 30-50\% of the cells showed spontaneous $\mathrm{Ca}^{2+}$ oscillations (Fig. 2A), but in pancreatic myofibroblasts no oscillation was observed. Fig. 2B shows a representative experiment in which oscillations occur in some cells, independently from each other. Note that not all cells show spontaneous oscillatory activity. Oscillations were not synchronized in neighbouring cells. We tested different confluency levels (10-50-100 \%) to see whether oscillation depends on the number of cells seeded onto the coverslip but we found no correlation (data not shown). Cells showed stable but greatly variable oscillation pattern from cell to cell with different amplitudes and frequencies. As the proportion of oscillating cells $(53.0 \pm 8.1 \%)$ was the highest in the gastric myofibroblasts (Fig. 2C), and they showed the highest oscillation frequency (Fig. 2D) we decided to focus our further experiments on HGMs There were no significant differences between the samples isolated from different patients. Amplitude data on oscillation were calculated by normalizing the amplitude of the wave to the baseline resting calcium signal ratio of F340/F380. HGMs displayed oscillatory activity with amplitudes of $1.67 \pm 0.062$ $(\mathrm{N}=4 / 10)$. Average frequency was $0.35 \pm 0.05$ oscillation/min $(\mathrm{N}=4 / 10)$. 


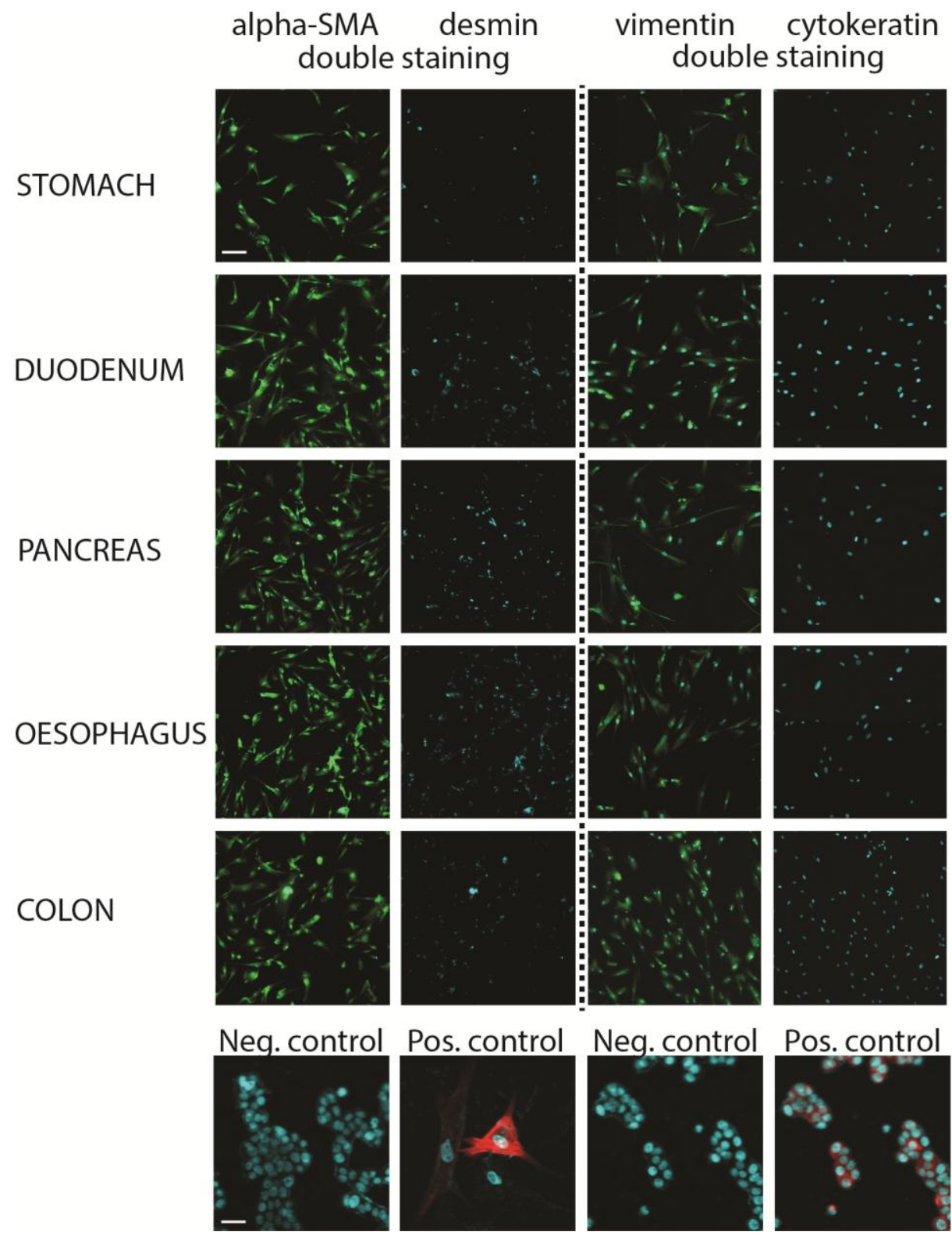

Fig. 1. Isolated human myofibroblasts from different tissues. Representative immunocytochemistry pictures of myofibroblasts isolated from the stomach, duodenum, pancreas, oesophagus and colon. $\alpha$-SMA stained sections were also counterstained with antibodies against desmin, vimentin or cytokeratin. Nuclei were counterstained with DAPI (blue). Cells showed positive staining for $\alpha$-SMA (left column) and vimentin (right column). Cytokeratin and desmin stainings were negative, so the cells were thereby considered myofibroblasts. White scale bar indicates $1 \mathrm{~mm}$. For positive and negative controls the white scale bar indicates $100 \mu \mathrm{M}$. For negative and cytokeratin positive controls, the Capan-1 pancreatic ductal cell line was used. Cultured cancer cells from human high grade pancreatic neuroendocrine carcinoma were used for positive control to desmin. $\mathrm{N}=2$. 
A

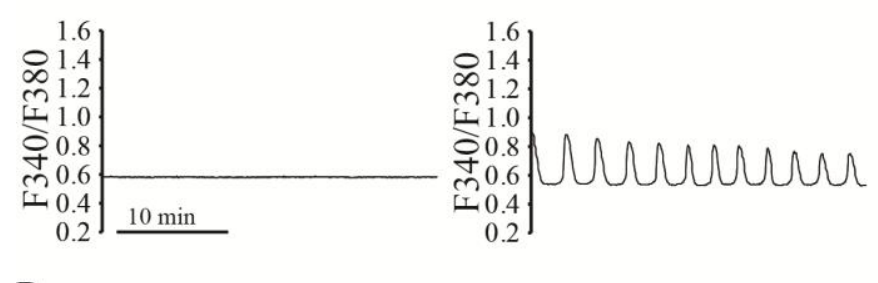

$\mathrm{B}$
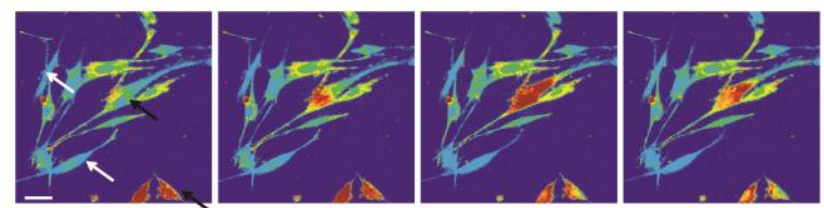

$0 \mathrm{sec}$

$5 \mathrm{sec}$

$10 \mathrm{sec}$

$15 \mathrm{sec}$
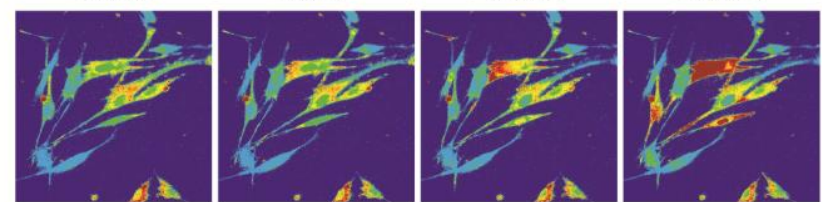

$20 \mathrm{sec}$

$25 \mathrm{sec}$

$30 \mathrm{sec}$

$35 \mathrm{sec}$
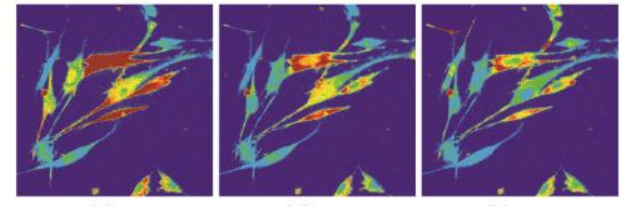

$50 \mathrm{sec}$

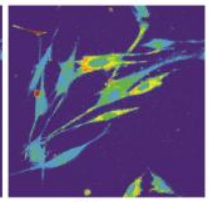

$55 \mathrm{sec}$
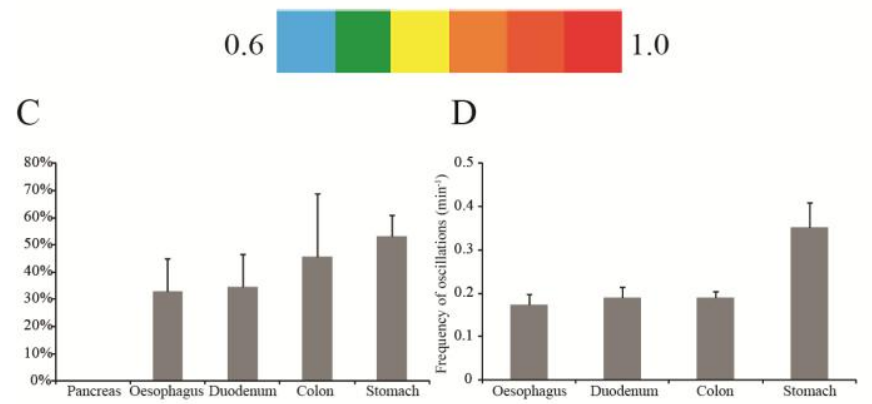

Fig. 2. Intracellular $\mathrm{Ca}^{2+}$ oscillations in human myofibroblasts. HGMs were seeded onto cover glass; after overnight incubation they were mounted on an inverted microscope and loaded with the $\mathrm{Ca}^{2+}$-sensitive fluorescent dye FURA2-AM to record changes in intracellular $\mathrm{Ca}^{2+}$ concentration. $A$ : Representative curves of different $\mathrm{Ca}^{2+}$ signals in standard Hepes solution in human gastric myofibroblasts (HGM). The diagram on the left side shows a non-oscillatory cell, while the right is a representative curve of an oscillatory cell. Note that spontaneous oscillatory waves are strictly monophasic. $B$ : The color pictures show a representative experiment in standard Hepes buffer bathed HGMs during FURA2-AM microfluorometry using 20x magnification. White arrows indicate cells showing no spontaneous $\mathrm{Ca}^{2+}$ oscillations, while black arrows indicate cells with spontaneous $\mathrm{Ca}^{2+}$ oscillations. White scale bar indicates $0.5 \mathrm{~mm}$. F340/F380 ratios are represented as colors as indicated in the color bar $(B$, bottom). The bars charts show $C$ : percentage of cells demonstrating oscillatory activity and $D$ : oscillatory frequencies in myofibroblasts isolated from different gastrointestinal organs. While pancreatic myofibroblasts showed no oscillatory activity, oesophageal, duodenal, colonic and gastric myofibroblasts demonstrated oscillation. The highest proportion of oscillatory cells was found in gastric myofibroblasts $(\mathrm{N}=6 / 5)$. 


\subsubsection{HGMs are positive for CD117 and PDGF-R, but negative for DOG1}

When focusing on the $\alpha$-SMA and vimentin positive HGMs (Fig. 3A), we performed a ki67 staining to determine if the proportion of oscillatory cells might correspond with cell cycle, ie. the $\mathrm{S}$ phase. We found that only $34 \pm 3.1 \%$ of cells stained positive for ki67 (Fig. 3B). As the maximum proportion of ki67 positive cells were always below $50 \%$, and in FURA-2AM experiments occasionally $100 \%$ of cells showed spontaneous oscillations. It can be concluded that oscillations are unlikely to be due to cell cycle, perhaps they are the result of cell division and migration together, which might explain the heterogeneity of $\mathrm{Ca}^{2+}$ oscillations.

As spontaneous intrinsic electrical activity is well-known in the interstitial cells of Cajal (ICC), we checked different ICC markers on HGMs (Fig. 3B). We found that HGMs stained positive for CD117, but negative for DOG1. As DOG1 is the most specific ICC marker ${ }^{55}$ and should correlate with CD117 staining, it can be concluded that CD117 is only a dedifferentiation marker in $\mathrm{HGMs}^{56}$. PDGF-R, a stromal myofibroblast marker, was also positive for the HGMs.

\subsubsection{Intracellular $\mathrm{Ca}^{2+}$ oscillations are dependent on the extracellular $\mathrm{Na}^{+}$and $\mathrm{Ca}^{2+}$}

We used ion withdrawal techniques on non-oscillating and oscillating HGMs (Fig. 4) in order to identify the mechanism responsible for the oscillatory activity. Withdrawal of $\mathrm{Ca}^{2+}$ from the extracellular solution caused no effect on non-oscillatory cells, but a cease of $\mathrm{Ca}^{2+}$ oscillation occurred in oscillatory cells (Fig. 4A). Re-addition of $\mathrm{Ca}^{2+}$ to the extracellular space made oscillatory cells to continue oscillation (Fig. 4A, right). Clearly, oscillation depends on extracellular $\mathrm{Ca}^{2+}$ indicating the role of a plasma membrane $\mathrm{Ca}^{2+}$ channel/transporter. $\mathrm{Na}^{+}$-removal also stopped oscillation and caused a relatively highamplitude single calcium wave in oscillatory and non-oscillatory cells as well (Fig. 4B), in some cases with repeated waves with fade-out effect (Fig. 4C). These findings suggest a $\mathrm{Na}^{+}-$ dependent $\mathrm{Ca}^{2+}$-transport mechanism in HGMs. Removal of both ions had no effect on nonoscillating cells but stopped oscillations in the other type (Fig. 4D). Oscillations returned immediately after re-addition of ions, which agrees with the former indication of a plasma membrane $\mathrm{Na}^{+}$-dependent $\mathrm{Ca}^{2+}$-exchange mechanism. Removal of $\mathrm{K}^{+}$before removing $\mathrm{Na}^{+}$ had no effect on the $\mathrm{Ca}^{2+}$ signalling in non-oscillating cells and did not stop oscillations in oscillatory cells (Fig. 4E), suggesting that the oscillations were $\mathrm{K}^{+}$independent. Removal of 
$\mathrm{Mg}^{2+}$ elevated the basal $\mathrm{Ca}^{2+}$ levels in HGMs, but in $16.8 \pm 3.6 \%(\mathrm{~N}=6)$ of the non-oscillating cells it caused $\mathrm{Ca}^{2+}$ oscillations (Fig. 4F). Furthermore, in oscillating HGMs $\mathrm{Mg}^{2+}$ removal had no effect on $\mathrm{Ca}^{2+}$ oscillations, suggesting that the oscillations are independent of $\mathrm{Mg}^{2+}$ (Fig. 4G).

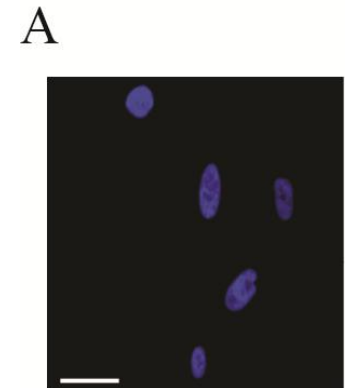

DAPI

B

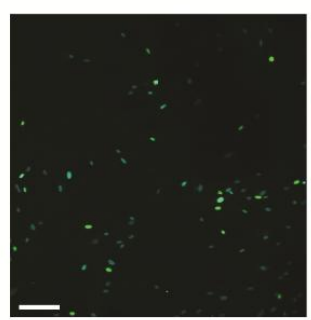

DAPI + ki67

C

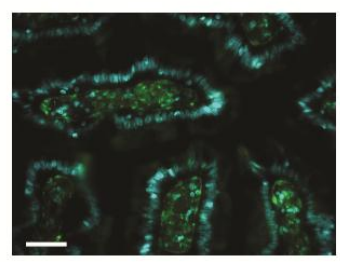

DAPI + PDGF-R

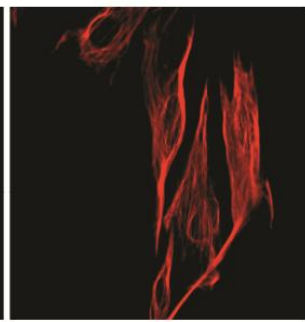

vimentin
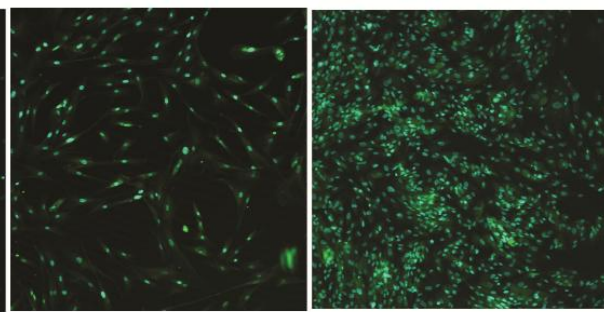

DAPI + PDGF-R DAPI + CD-117

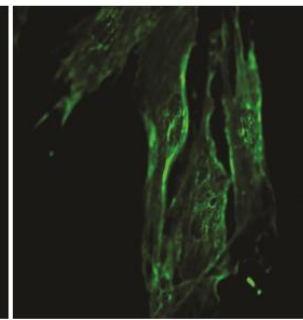

$\alpha-\mathrm{SMA}$

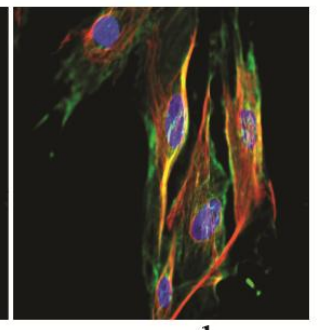

merged
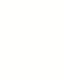
A

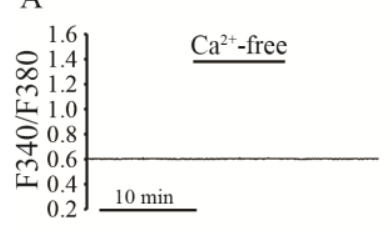

$\mathrm{B}$

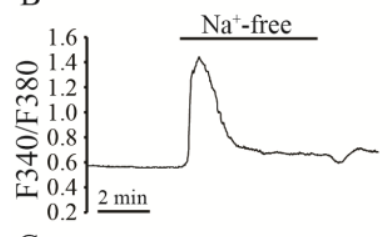

$\mathrm{C}$

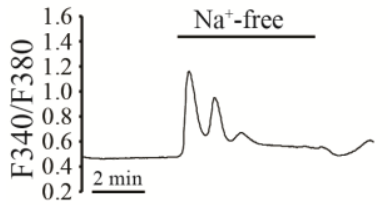

D

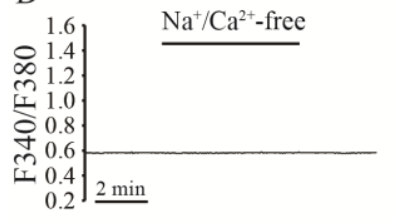

E
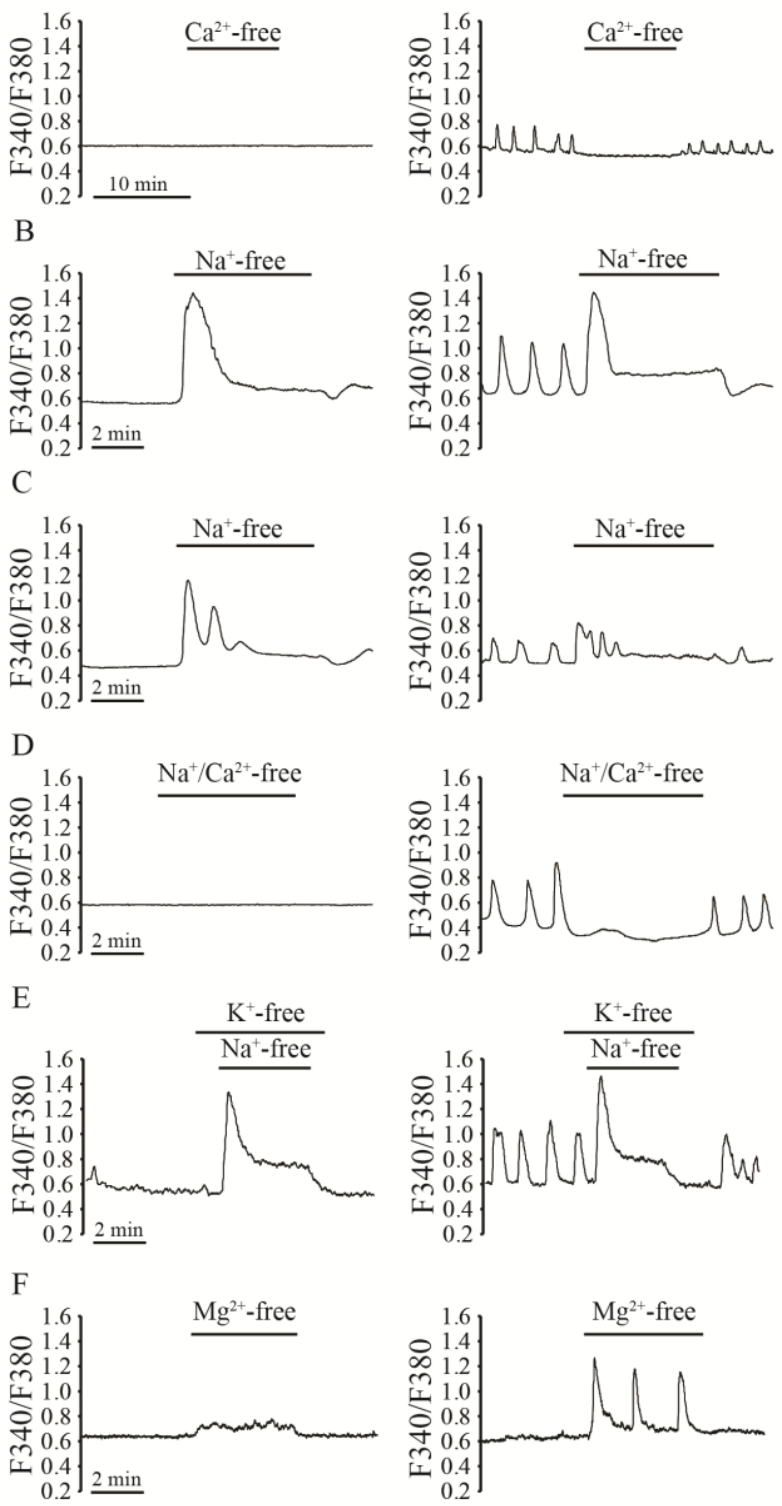

G

$\mathrm{Mg}^{2+}$-free
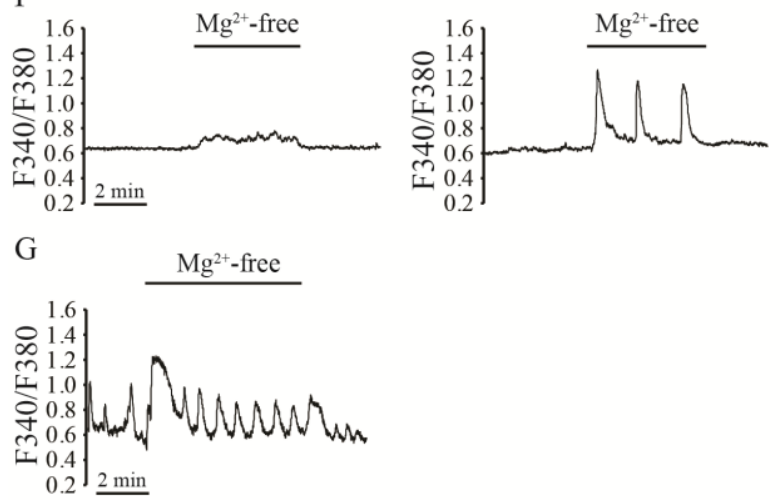

Fig. 4. Intracellular $\mathrm{Ca}^{2+}$ oscillations are dependent on the extracellular $\mathrm{Ca}^{2+}$ and $\mathrm{Na}^{+}$. Representative intracellular traces of different $\mathrm{Ca}^{2+}$ signals provoked with ion withdrawal techniques in HGMs during FURA2AM microfluorometry. Calcium $(A)$, sodium ( $B$ and $C$ ), calcium and sodium $(D)$, potassium then sodium removal $(E)$ in non-oscillatory (left) and non-oscillatory cells (right) Removal of magnesium elevated the intracellular calcium levels of non-oscillatory cells $(F$, left $)$, but in some cells $(16.8 \pm 3.6 \%)$ it caused calcium oscillations $(F$, right $)$. Magnesium withdrawal did not affect calcium oscillations $(G)$. Note that spontaneous oscillatory waves were strictly monophasic. $\mathrm{N}=8 / 10$. 


\subsubsection{Intracellular sodium also depends on extracellular sodium and calcium}

Suspecting the presence of a $\mathrm{Na}^{+}$-dependent $\mathrm{Ca}^{2+}$ exchange mechanism in HGMs, we determined to investigate the effects of ion withdrawal techniques on the intracellular $\mathrm{Na}^{+}$ $\left(\left[\mathrm{Na}^{+}\right]_{\mathrm{i}}\right)$ levels using SBFI-AM dye. Withdrawal of the extracellular $\mathrm{Ca}^{2+}$ caused an increase in the $\left[\mathrm{Na}^{+}\right]_{\mathrm{i}}$ (Fig. 5A, right), meaning that not only extracellular $\mathrm{Na}^{+}$regulates the intracellular $\mathrm{Ca}^{2+}\left(\left[\mathrm{Ca}^{2+}\right]_{\mathrm{i}}\right)$, but $\mathrm{Na}^{+}$and $\mathrm{Ca}^{2+}$ regulate each other's entry to the cells. Removal of extracellular $\mathrm{Na}^{+}$caused a decrease in $\left[\mathrm{Na}^{+}\right]_{\mathrm{i}}$ (Fig. 5B, left). Removal of both $\mathrm{Na}^{+}$and $\mathrm{Ca}^{2+}$ also decreased the $\left[\mathrm{Na}^{+}\right]_{\mathrm{i}}$ (Fig. $5 \mathrm{~B}$, right), however the decrease was greater with the presence of extracellular $\mathrm{Ca}^{2+}$ (Fig5C). Not only the absolute change of the fluorescence (Fig. 5C, left), but the relative change to the baseline fluorescence (Fig. 5C, right) was also significantly different in the presence of extracellular $\mathrm{Ca}^{2+}$, providing another functional evidence for the presence of a plasma membrane NCX.

A
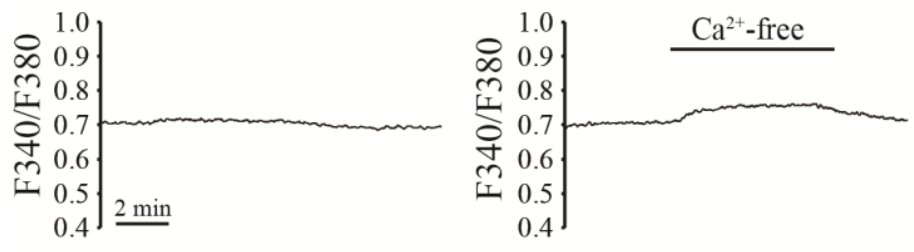

B
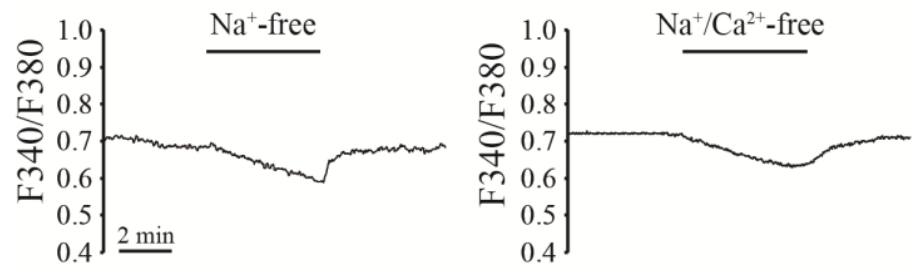

$\mathrm{C}$
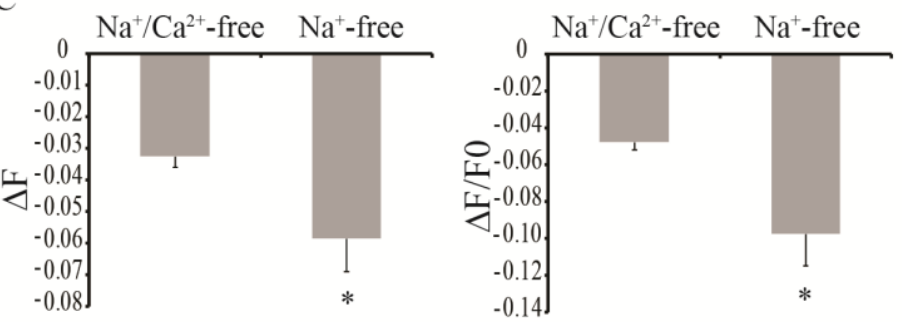

Fig. 5. Intracellular $\mathrm{Na}^{+}$depends on the extracellular $\mathrm{Ca}^{2+}$ and $\mathrm{Na}^{+}$. Representative traces of different intracellular $\mathrm{Na}^{+}$signals provoked with ion withdrawal technique in HGMs during SBFI-AM microfluorometry $(A$ and $B) . C$ : the absolute (left) and relative (normalized to the baseline, right) change in fluorescence after ion withdrawals techniques. Data are shown as means \pm SEM. *: $\mathrm{p}<0.05 \mathrm{vs}$. $\mathrm{Na}^{+} / \mathrm{Ca}^{2+}$-free, $\mathrm{N}=4 / 10$. 


\subsubsection{Effect of different $\mathrm{Ca}^{2+}$-transport inhibitors on the intracellular $\mathrm{Ca}^{2+}$ and $\mathrm{Na}^{+}$levels of HGMs}

Cells were constantly perfused with standard HEPES solution with or without reagents. We tested L-type $\mathrm{Ca}^{2+}$ channel blocker verapamil and NCX blockers CB-DMB and $\mathrm{NiCl}_{2}$ (Fig. 6). The amiloride-derivative pan-NCX inhibitor $\mathrm{CB}-\mathrm{DMB}$ in $1 \mu \mathrm{M}$ concentration reversibly lowered $\left[\mathrm{Ca}^{2+}\right]_{\mathrm{i}}$ (Fig. $6 \mathrm{~A}$ ), while stopping its administration recovered $\left[\mathrm{Ca}^{2+}\right]_{\mathrm{i}}$, but did not affect oscillation. However, it should be noted, that CB-DMB $1 \mu \mathrm{M}$ concentration inhibited only $31.2 \%$ of HGMs, but higher concentrations inhibited all HGMs. The administration of $10 \mu \mathrm{M}$ CB-DMB resulted in a decrease in $\left[\mathrm{Ca}^{2+}\right]_{\mathrm{i}}$ in all oscillatory and non-oscillatory cells (Fig. 6B). Also there was no significant difference in $\left[\mathrm{Ca}^{2+}\right]_{i}$ decrease when non-oscillatory cells were treated with $1 \mu \mathrm{M}$ or $10 \mu \mathrm{M}$ concentrations of CB-DMB (Fig. 6A vs. B). $1 \mathrm{mM}$ $\mathrm{NiCl}_{2}$ - another potent pan-NCX inhibitor - slightly decreased $\left[\mathrm{Ca}^{2+}\right]_{\mathrm{i}}$ with a small overshoot after stopping its administration (Fig. $6 \mathrm{C}$, left). $1 \mathrm{mM} \mathrm{NiCl}_{2}$ stopped oscillation in oscillatory cells but it came back after stopping the administration (Fig. 6C, right). These findings also confirm that spontaneous oscillation is most likely maintained by NCX or at least it is involved in generating/maintaining oscillations.

$10 \mu \mathrm{M}$ and $100 \mu \mathrm{M}$ verapamil had no effect on $\left[\mathrm{Ca}^{2+}\right]_{\mathrm{i}}$ (Fig. 6D) suggesting that the oscillation is probably not voltage-mediated. Administering CB-DMB in 1 and $10 \mu \mathrm{M}$ concentrations resulted in a decreased $\left[\mathrm{Na}^{+}\right]_{\mathrm{i}}$ level, but there was no significant difference between the two concentrations (Fig. 6E). The other NCX inhibitor $\mathrm{NiCl}_{2}$ did not alter significantly the $\left[\mathrm{Na}^{+}\right]_{i}$ (Fig. $6 \mathrm{~F}$ ). These results suggest the importance of NCX not only in the regulation of $\left[\mathrm{Ca}^{2+}\right]_{i}$, but also in the maintenance of the $\left[\mathrm{Na}^{+}\right]_{\mathrm{i}}$ in $\mathrm{HGM}$ cells.

\subsection{7. mRNA and protein expression of NCX in HGMs}

Based on the functional experiments we investigated the presence of the NCX isoforms at the mRNA and protein levels. Reverse transcription PCR confirmed the mRNA expression of all three NCX isoforms (Fig. 7A) on a transplant patient (left columns) and on a cancer patient (right columns), which was confirmed by DNA sequencing. Immunocytochemistry revealed that NCX1, NCX2 and NCX3 are also present at the protein level in HGMs (Fig. 7B). 
A
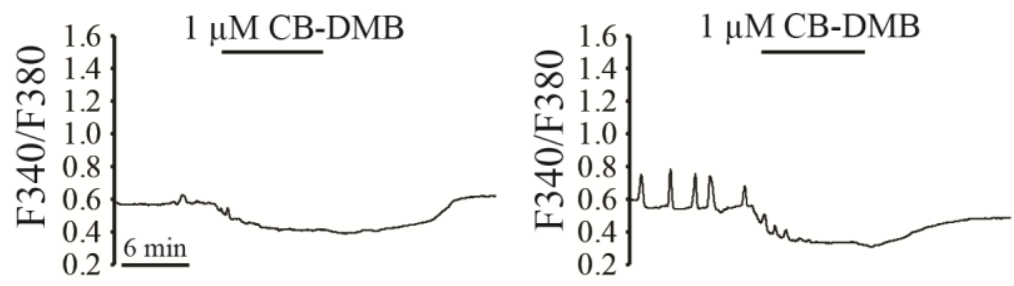

B
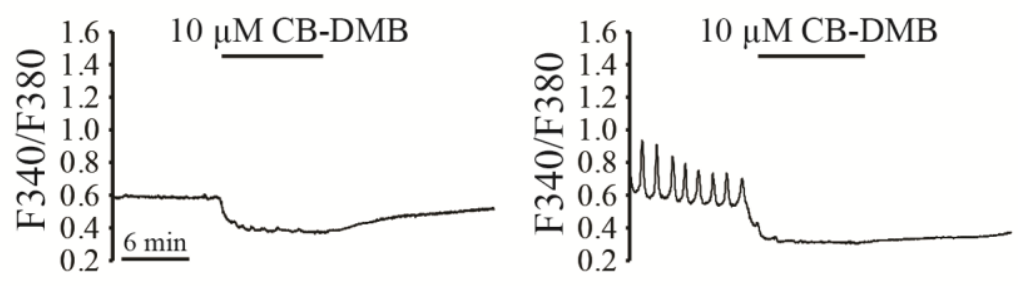

$\mathrm{C}$
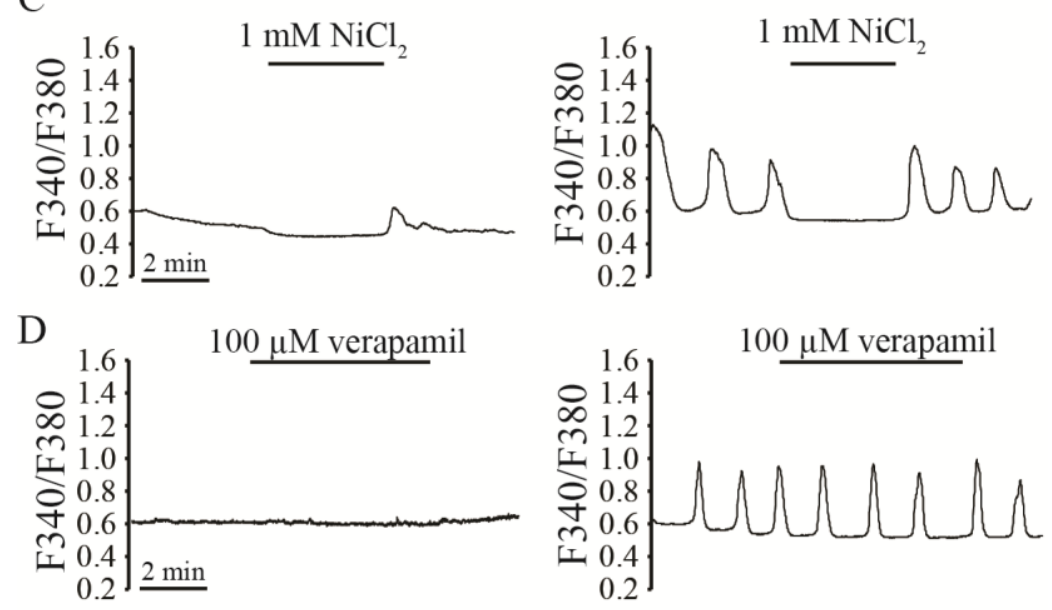

$\mathrm{E}$
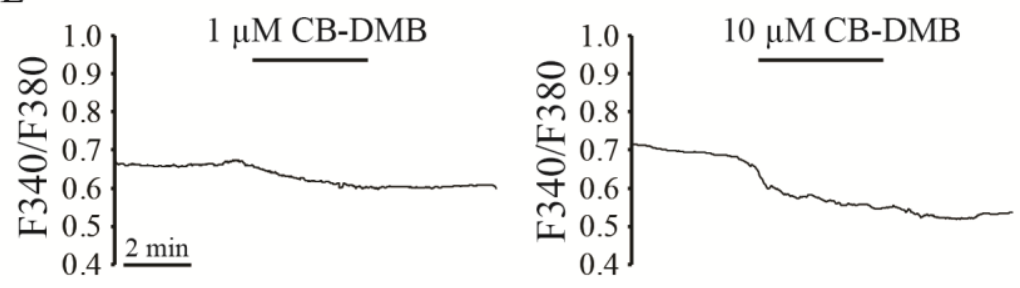

$\mathrm{F}$

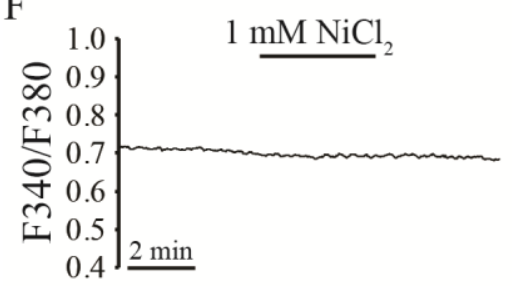

Fig. 6. The effect of $\mathrm{Na}^{+} / \mathrm{Ca}^{2+}$ exchanger (NCX) inhibitors on the intracellular $\mathrm{Ca}^{2+}$ and $\mathrm{Na}^{+}$concentration of HGMs. Effects of $1 \mu \mathrm{M}(A), 10 \mu \mathrm{M}(B) \mathrm{CB}-\mathrm{DMB}, 1 \mathrm{mM} \mathrm{NiCl}_{2}(C)$ and $100 \mu \mathrm{M}$ verapamil $(D)$ in nonoscillatory (left) and oscillatory (right) HGMs on intracellular $\mathrm{Ca}^{2+}$ concentration $\left(\left[\mathrm{Ca}^{2+}\right]_{\mathrm{i}}\right)$ in HGMs. The intracellular $\mathrm{Na}^{+}$concentration $\left(\left[\mathrm{Na}^{+}\right]_{\mathrm{i}}\right)$ in SBFI-AM microfluorometric experiments, when inhibiting NCX with 1 and $10 \mu \mathrm{M} \mathrm{CB}-\mathrm{DMB}(E)$, and $1 \mathrm{mM} \mathrm{NiCl} l_{2}(F) . \mathrm{N}=4 / 10$. 
A

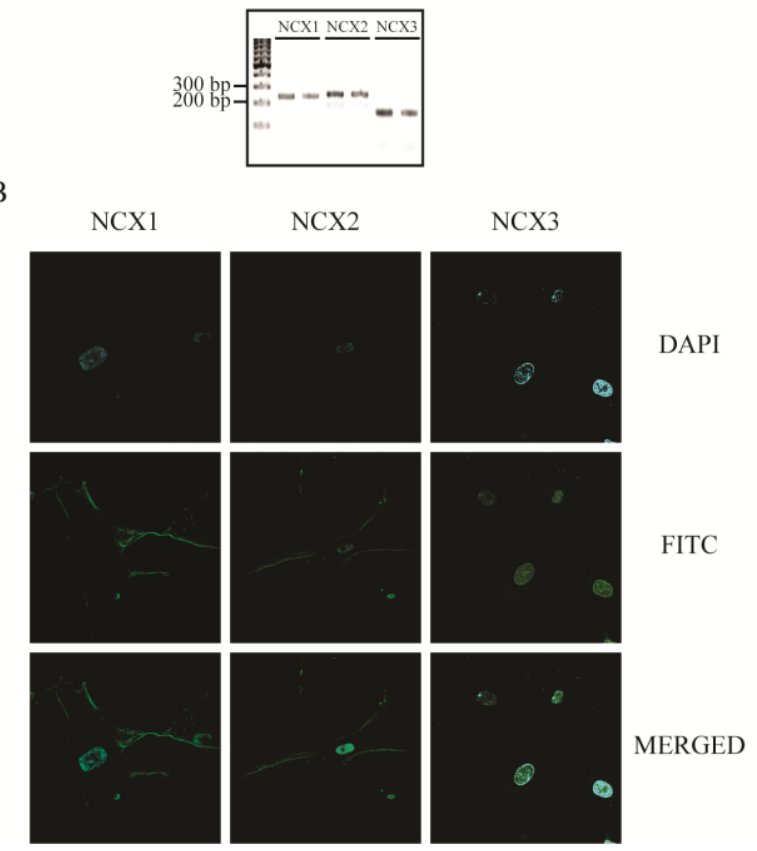

Fig. 7. NCX mRNA and protein are expressed in HGMs. A: Reverse transcription PCR confirmed the mRNA expression of NCX1, NCX2 and NCX3 $(n=2)$ in HGMs. Left columns are PCR products from cadaver donors, right columns are from gastric cancer patients healthy tissue. Expected PCR product sizes are: NCX1, 231 bp; NCX2, 243 bp; NCX3, 154 bp. In water blind experiments, water was used as template. B: Immunocytochemistry revealed that NCX1, NCX2 and NCX3 are present in HGMs. White scale bar indicates $50 \mu \mathrm{m}$. No specific staining was detected when the primary antibodies were omitted (data not shown). N=3.

\subsubsection{Measuring $\mathrm{Na}^{+} / \mathrm{Ca}^{2+}$ exchanger current}

After the microspectrofluorometry measurements the electrogenic features of the cells were examined with whole-cell configuration of the patch clamp technique. For recording the NCX current $\left(\mathrm{I}_{\mathrm{NCX}}\right)$, special $\mathrm{K}^{+}$-free bath and pipette solutions were used (see above) in order to block the $\mathrm{Na}^{+}-, \mathrm{Ca}^{2+}-, \mathrm{K}^{+}$-currents and the $\mathrm{Na}^{+} / \mathrm{K}^{+}$pump current. The descending limb of the ramp was used to plot the I-V curve (Fig. 8A). The cell capacitance was measured by applying at $10 \mathrm{mV}$ hyperpolarizing pulse from $-10 \mathrm{mV}$. The holding potential was $-90 \mathrm{mV}$. The capacity was calculated by integration of the capacitive transient divided by the amplitude of the voltage step $(10 \mathrm{mV})$.

The NCX ( $\mathrm{NiCl}_{2}$ sensitive) current (Fig. 8B, left), was not measurable in HGMs, however the same protocol applied to cardiomyocytes resulted in a measurable NCX current (Fig. 8B, right). Probably this is a result due to the low number or density of the NCX expressed on the surface of the HGMs. 


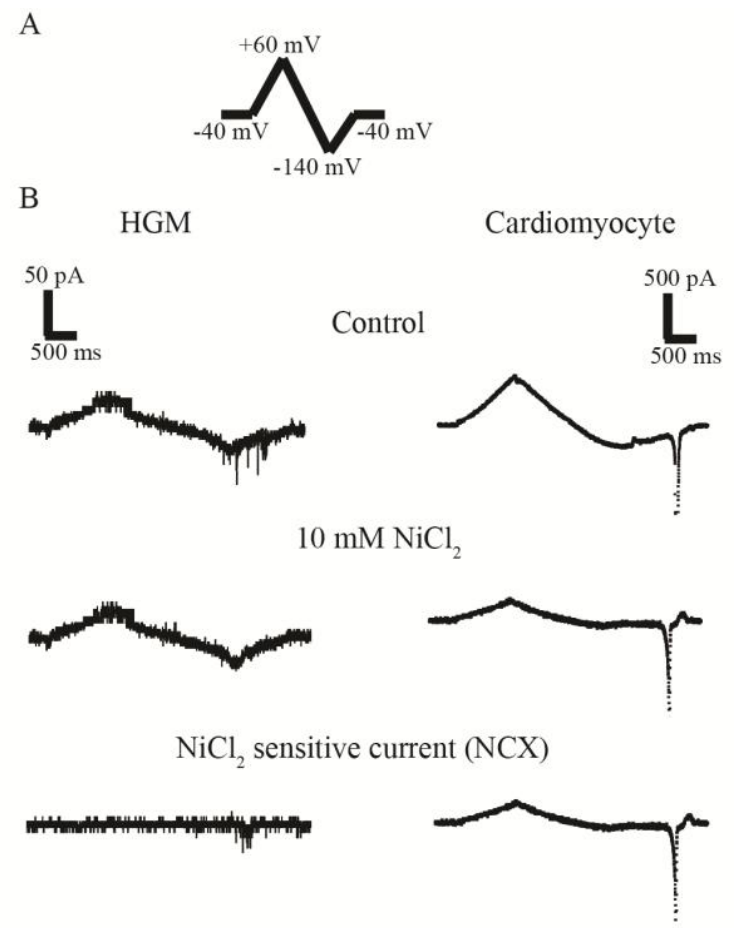

Fig. 8. Lack of measurable $\mathrm{Na}^{+} / \mathrm{Ca}^{2+}$ exchanger current in HGMs. A: The current-voltage (I-V) relationship of $\mathrm{I}_{\mathrm{NCX}}$ current was measured by ramp pulses. The cells were initially depolarized the holding potential of -40 $\mathrm{mV}$ to $60 \mathrm{mV}$, then hyperpolarized to $-140 \mathrm{mV}$ and depolarized back to the holding potential. NCX current was recorded as $\mathrm{Ni}^{2+}$ sensitive current using the descending limb of the ramp protocol. B: Representative current traces recorded from HGMs (left) and in control dog cardiomyocytes (right) in $\mathrm{K}^{+}$-free bath solution for control (top), after addition of $10 \mathrm{mM} \mathrm{NiCl}$ (middle). The NCX current is the $\mathrm{Ni}^{2+}$-sensitive current (bottom): i.e. subtracting the trace recorded in the presence of $10 \mathrm{mM} \mathrm{NiCl}_{2}$ from that measured in the absence of $\mathrm{NiCl}_{2}, \mathrm{~N}=5$.

\subsubsection{Motility decreased by NCX inhibitors}

In scratch wound migration assays we utilized the inhibitors to examine their effects on the motility of HGMs (Fig. 9A). $1 \mu \mathrm{M} \mathrm{CB}-\mathrm{DMB}$ and $1 \mathrm{mM} \mathrm{NiCl} 2$ significantly decreased motility (by $28.4 \pm 3.9 \%$ and $34.3 \pm 6.6 \%$ ) compared to the basal level (Fig. 9B). Stimulating migration with $100 \mathrm{ng} / \mathrm{ml}$ insulin-like growth factor II (IGF-II) caused a two-fold increase in motility (203.9 $\pm 9.8 \%$ vs. basal). $1 \mu \mathrm{M}$ CB-DMB significantly inhibited stimulated migration (by $65.6 \pm 8.4 \%$ ), whereas $1 \mathrm{mM} \mathrm{NiCl}_{2}$ treatment caused the strongest inhibition $(98.9 \pm 10.9$ vs. 203.9 $\pm 9.8 \%$ ) (Fig. 9B). We tried to use higher concentrations of CB-DMB to test dosedependency but the cells detached above $1 \mu \mathrm{M}$ after a few hours. 
A

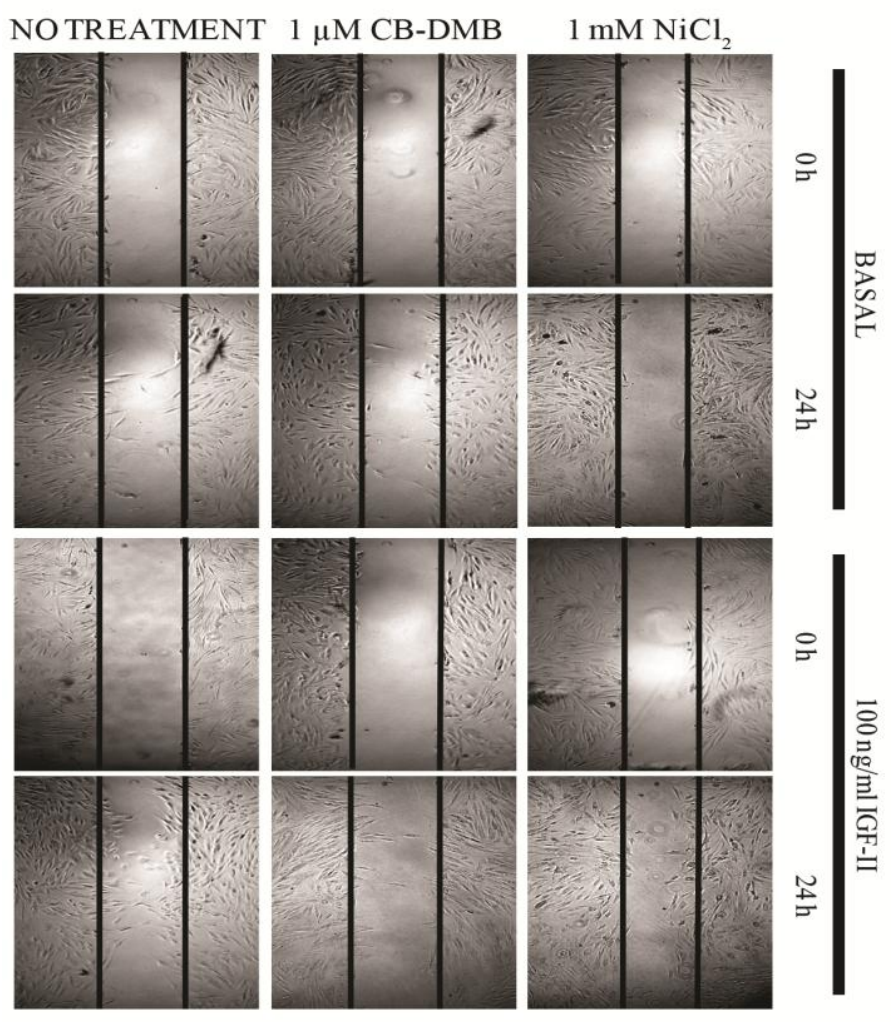

B

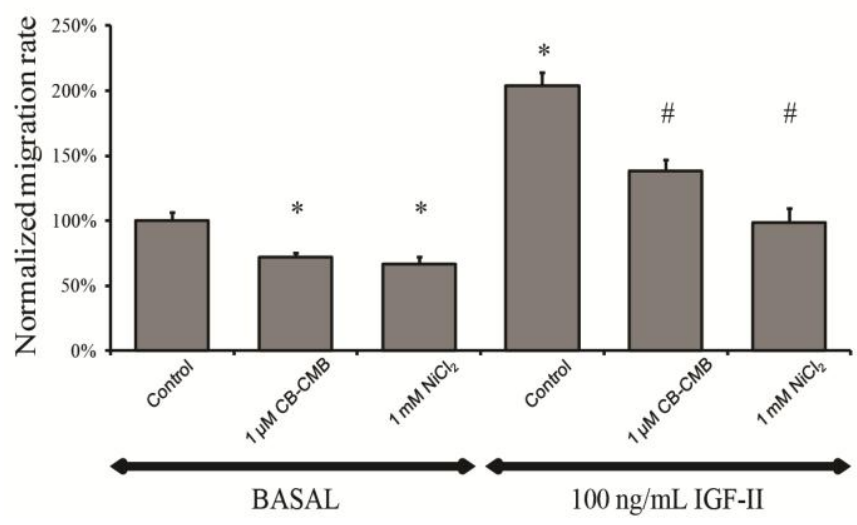

Fig. 9. Motility is decreased by NCX inhibitors in HGMs. A: Raw images taken at 0 and $24 \mathrm{~h}$ from scratch wound migration assays. HGMs were treated with different inhibitors with or without $100 \mathrm{ng} / \mathrm{ml}$ insulin-like growth factor II (IGF-II) treatment. Black lines mark the original wound edges at Oh. From these edges HGMs made their way into the cleared area by moving toward the opposite direction. Under basal conditions (without $100 \mathrm{ng} / \mathrm{ml}$ IGF-II stimulation) HGMs showed poor motility in serum-free media after $24 \mathrm{~h} .1 \mu \mathrm{M} \mathrm{CB}-\mathrm{DMB}$ and $1 \mathrm{mM} \mathrm{NiCl} 2$ decreased the number of migrated cells. In response to $100 \mathrm{ng} / \mathrm{ml}$ IGF-II stimulation, the basal migration rate elevated, more cells migrated into the scratched wound area and all the inhibitors seemed to decrease motility. $B$ : The bar chart shows normalized migration rates from the experiment shown in $A$. The number of cells migrated into the wound area under basal conditions without any treatment was considered as $100 \%$. Data are shown as means \pm SEM. *: p<0.05 vs. basal, \#: p<0.05 vs. 100 ng/ml IGF-II basal, N=4. 


\subsection{Proliferation is inhibited by blocking NCX}

Next we tested whether NCX inhibitors have an impact on cell division (Fig. 10). $100 \mathrm{ng} / \mathrm{ml}$ IGF-II was applied to stimulate proliferation of HGMs. We found that CB-DMB $(1 \mu \mathrm{M})$ inhibited cell division (by $55.8 \pm 5.5 \%$ ), while $1 \mathrm{mM} \mathrm{NiCl}_{2}$ caused a $78.3 \pm 5.9 \%$ decrease in cell proliferation without IGF-II stimulation (Fig. 10B). $100 \mathrm{ng} / \mathrm{ml}$ IGF-II stimulation increased basal proliferation rate to nearly two-fold (191.3 $\pm 10.1 \%) .1 \mu \mathrm{M}$ CB-DMB greatly inhibited cell division, but $1 \mathrm{mM} \mathrm{NiCl} 2$ caused the strongest inhibition in the IGF-II stimulated HGMs.

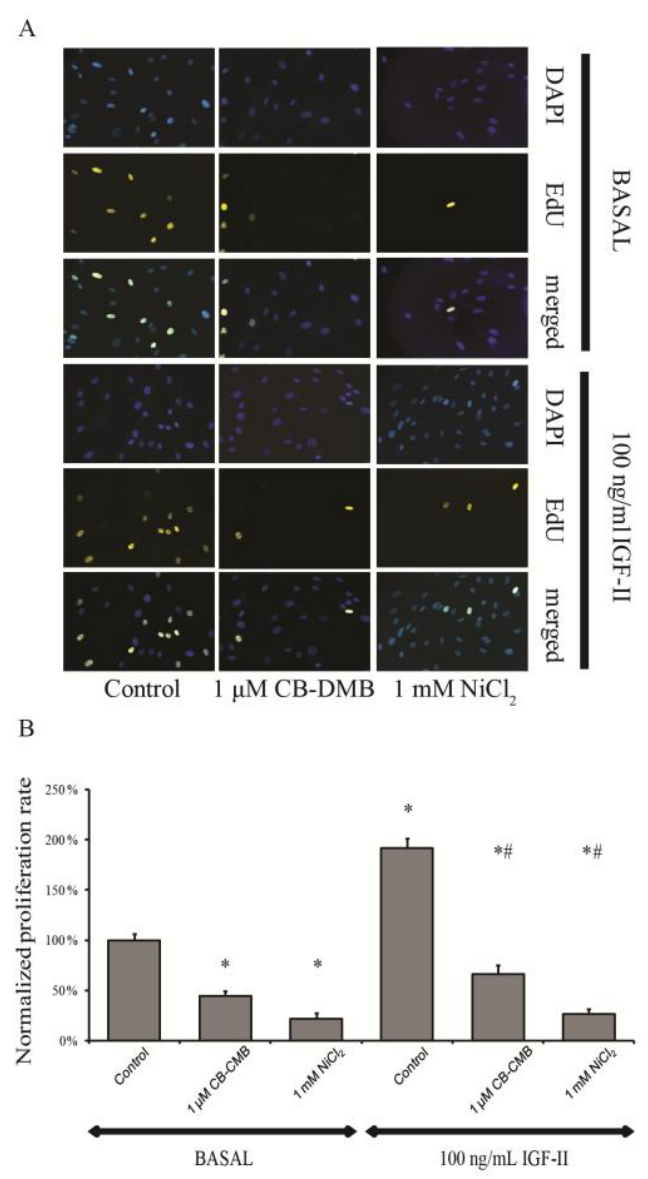

Fig. 10. NCX inhibition decreases proliferation rates in HGMs. A: HGMs were seeded onto cover glasses then subjected to EdU click-it immunocytochemistry. The figure shows representative pictures from EdU (yellow) immunocytochemistry proliferation assays with DAPI (blue) nuclei staining. HGMs were treated with NCX inhibitors and/or $100 \mathrm{ng} / \mathrm{ml}$ IGF-II. The administration of inhibitors decreased the number of EdU positive cells under basal conditions. $100 \mathrm{ng} / \mathrm{ml}$ IGF-II significantly increased EdU positivity, while all inhibitors seemed to greatly inhibit this stimulatory effect. $B$ : The bar chart shows normalized proliferation rates from experiments in $A$. Number of EdU positive cells at basal conditions without any treatment was considered as $100 \%$. Data are shown as means \pm SEM.* $p<0.05$ vs. basal, \#: $p<0.05$ vs. $100 \mathrm{ng} / \mathrm{ml}$ IGF-II stimulated, N=3. 


\subsection{POA increases intracellular calcium levels in PDEC}

\subsubsection{POA depletes ER $\mathrm{Ca}^{2+}$ stores of Capan-1 pancreatic ductal cells}

The administration of $200 \mu \mathrm{M}$ POA evoked sustained $\left[\mathrm{Ca}^{2+}\right]_{i}$ rise (Figure 4.A,B) in Capan1cells. Removal of extracellular $\mathrm{Ca}^{2+}$ had no effect on the $\Delta$ Ratio ${ }_{\text {max }}$ (Figure 11.A), suggesting that the initial rise in $\left[\mathrm{Ca}^{2+}\right]_{\mathrm{i}}$ is extracellular calcium independent. However, the plateau-phase of the signal was totally dependent on the presence of extracellular $\mathrm{Ca}^{2+}$ and blocked by gadolinium, suggesting the involvement of the store operated $\mathrm{Ca}^{2+}$ channels (Figure $11 \mathrm{~A}$ ). To verify that $200 \mu \mathrm{M}$ POA completely depletes the $\mathrm{ER} \mathrm{Ca}^{2+}$ stores, we administrated POA in $\mathrm{Ca}^{2+}$-free media followed by the administration of $2 \mu \mathrm{M}$ thapsigargin (Tg; sarcoplasmic/endoplasmic reticulum calcium ATPase (SERCA) inhibitor). Under these conditions $\mathrm{Tg}$ was not able to induce further $\mathrm{Ca}^{2+}$ release (Figure 12.A). For control we administered Tg prior to POA administration, where POA had no effect on $\left[\mathrm{Ca}^{2+}\right]_{\mathrm{i}}$. These data indicate that POA completely depletes the $\mathrm{ER} \mathrm{Ca}^{2+}$ stores and induces extracellular $\mathrm{Ca}^{2+}$ influx.

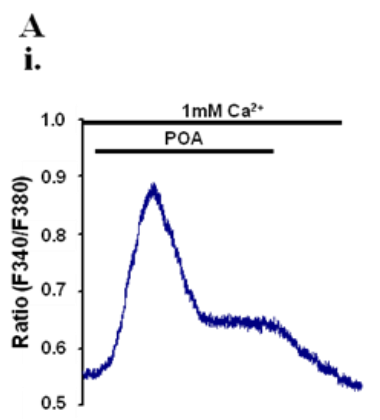

ii.

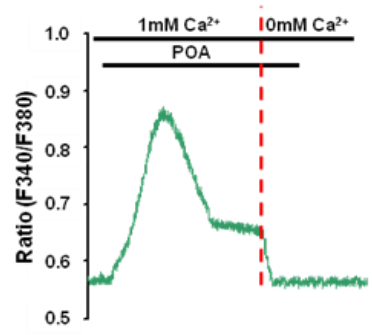

iii.

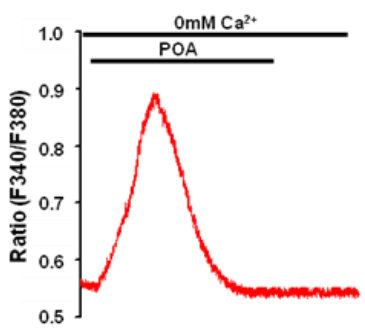

iv.

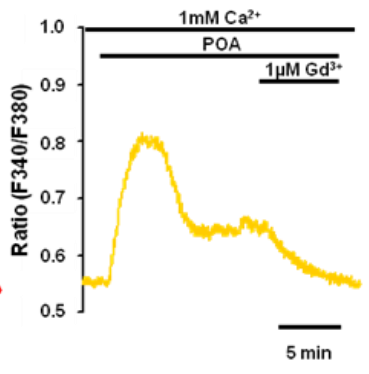

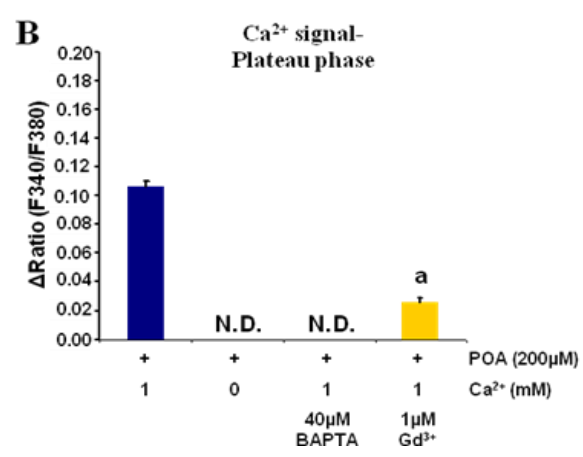

Figure 11. (A) The plateau phase of the POA-induced $\mathrm{Ca}^{2+}$ signal depends on extracellular $\mathrm{Ca}^{2+}$ influx. Representative curves show the effect of the administration of (i) $200 \mu \mathrm{M}$ POA on $\left[\mathrm{Ca}^{2+}\right]_{i}$. (ii) The removal of the extracellular $\mathrm{Ca}^{2+}$ during the plateau phase of the $\mathrm{Ca}^{2+}$ signal abolished the $\mathrm{Ca}^{2+}$ elevation. (iii) The plateau phase was completely absent in $\mathrm{Ca} 2+-$ free extracellular solution and (iv) was significantly inhibited by the administration of $1 \mu \mathrm{M} \mathrm{Gd}^{3+}$. (B) Summary data of the $\triangle$ Ratio of the plateau phase of the POA-induced $\mathrm{Ca}^{2+}$ signal. The plateau phase of the POA induced $\mathrm{Ca}^{2+}$ signal was completely based on extracellular $\mathrm{Ca}^{2+}$ influx. Data are shown as means \pm SEM. n: 3-5 experiments for all groups. N.D.: not detected. a: $\mathrm{p}<0.05$ vs Plateau phase. 


\subsubsection{POA decreases PMCA activity in Capan-1 cells}

To further characterize the effects of POA on the extracellular $\mathrm{Ca}^{2+}$ influx, we performed the $\mathrm{Tg}_{-} \mathrm{Ca}^{2+}$ re-addition protocol ${ }^{57}$ (Figure 12.B,C). Tg treatment depleted ER $\mathrm{Ca}^{2+}$ and the readdition of extracellular $\mathrm{Ca}^{2+}$ evoked store operated $\mathrm{Ca}^{2+}$ influx, where the steady state is

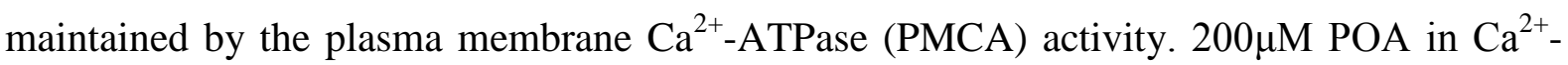
free extracellular solution mimicked the effect $\mathrm{Tg}$ (depleted the $\mathrm{ER}^{\mathrm{Ca}}{ }^{2+}$ store and induced SOCE). However, after the SOCE mediated $\mathrm{Ca}^{2+}$ rise the decrease of $\left[\mathrm{Ca}^{2+}\right]_{\mathrm{i}}$ was markedly slower than in the case of Tg-treated cells and the plateau was reached on an elevated $\left[\mathrm{Ca}^{2+}\right]_{\mathrm{i}}$. These results suggest that POA not only depletes $\mathrm{ER} \mathrm{Ca}^{2+}$ stores and induce extracellular $\mathrm{Ca}^{2+}$ influx, but also decreases PMCA activity, which can further contribute to the sustained $\mathrm{Ca}^{2+}$ elevation.

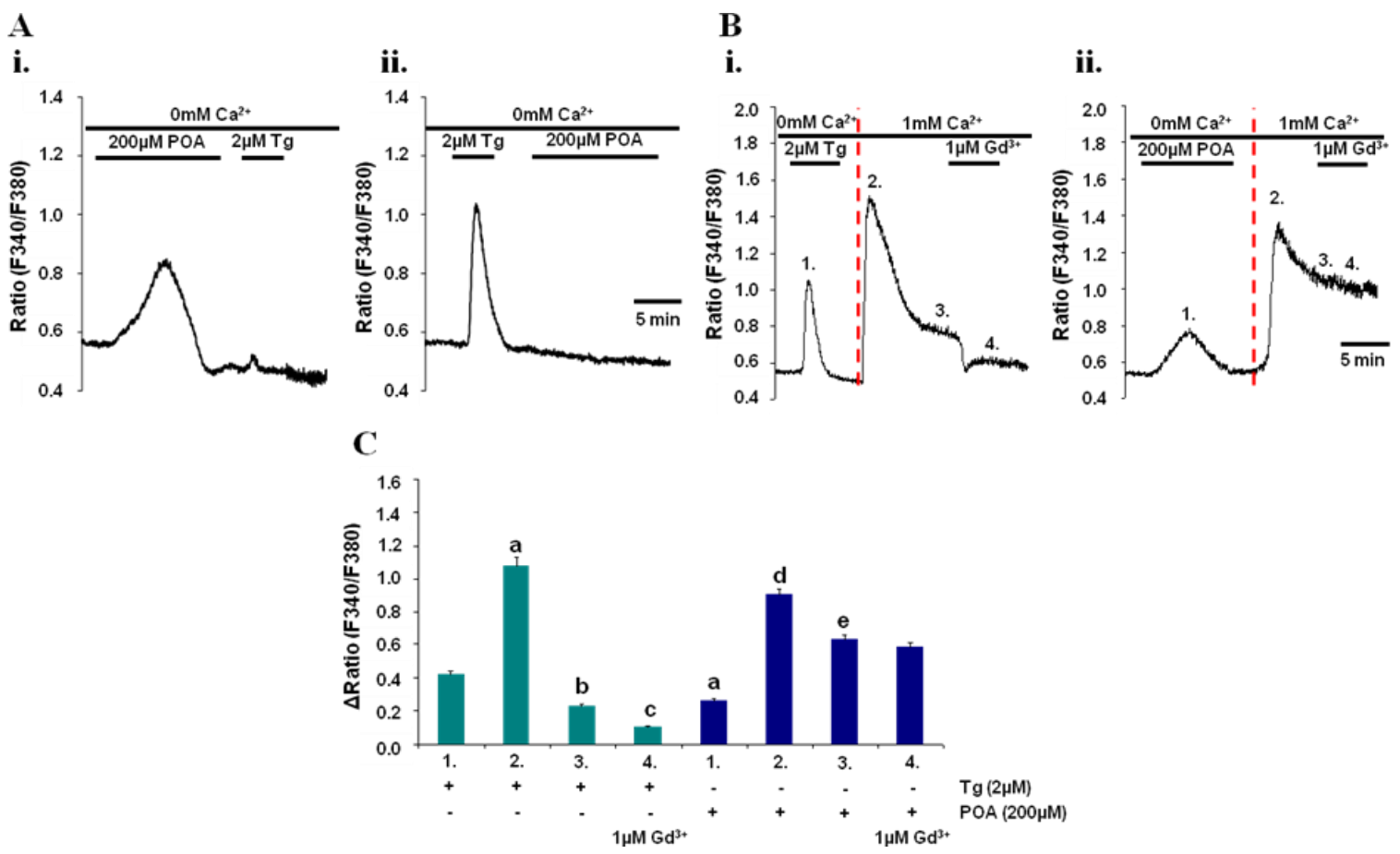

Figure 12. (A) The administration of $200 \mu \mathrm{M} P O A$ completely depletes the $\mathrm{ER} \mathrm{Ca}^{2+}$ stores. (i) After the administration of $200 \mu \mathrm{M}$ POA the SERCA inhibitor thapsigarin (Tg) was not able to induce further $\mathrm{Ca}^{2+}$ release. (ii) Similarly, POA was not able to induce further $\mathrm{Ca}^{2+}$ release after $\mathrm{Tg}$ administration. (B-C) The administration of $200 \mu \mathrm{M}$ POA induces store operated extracellular $\mathrm{Ca}^{2+}$ influx. (i) The administration of $2 \mu \mathrm{M} \mathrm{Tg}$ in $\mathrm{Ca}^{2+}$ - free extracellular solution depleted the $\mathrm{ER} \mathrm{Ca}^{2+}$ store (1.). The re-addition of the extracellular $\mathrm{Ca}^{2+}$ induced rapid $\left[\mathrm{Ca}^{2+}\right]_{\mathrm{i}}$ elevation (2.) which was followed by a decrease and an equilibrium (3.). $\mathrm{Gd}^{3+}$ significantly decreased the $\mathrm{Ca}^{2+}$ influx (4.). (ii) $\mathrm{The}$ administration of $200 \mu \mathrm{M}$ POA in $\mathrm{Ca}^{2+}$-free extracellular solution also depleted the $\mathrm{ER} \mathrm{Ca}^{2+}$ store (1.) which was followed by $\left[\mathrm{Ca}^{2+}\right]_{i}$ elevation after the re-addition of the extracellular $\mathrm{Ca}^{2+}\left(2\right.$.). The decrease after the maximal $\mathrm{Ca}^{2+}$ elevation was slower than in the case of the $\mathrm{Tg}$ treated cells and the equilibrium was reached on an elevated $\left[\mathrm{Ca}^{2+}\right]_{i}$ level (3.) which suggest the failure of the PMCA. $\mathrm{Gd}^{3+}$ had no effect on the $\mathrm{Ca}^{2+}$ influx in this case (4.). a: $\mathrm{p}<0.05$ vs

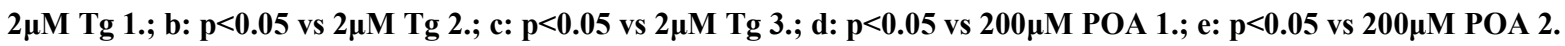




\subsection{SP inhibits pancreatic ductal bicarbonate secretion via NK2 and NK3 receptors in guinea pig exocrine pancreas}

\subsubsection{NK2 and NK3 receptors are expressed on the lateral and luminal membranes of intra/interlobular ducts}

Immunohistochemical staining revealed that all $3 \mathrm{NK}$ receptors were expressed in pancreatic ductal cells; however, their localizations were different (Figs. 13C,E). Neurokinin 1 receptor was exclusively localized to the luminal membrane (Fig. 13C), whereas positive staining of NK2 (Fig. 13D) and NK3 (Fig. 13E) receptors were observed both on the lateral and luminal membranes of intra/interlobular ducts.

\subsubsection{Inhibitory effect of $S P$ on pancreatic ductal bicarbonate secretion is mediated by $\mathrm{NK} 2$ and $\mathrm{NK} 3$ receptors}

First, we investigated the bicarbonate secretory rate of intact pancreatic ducts using the alkali load technique. Exposing ducts to $20 \mathrm{mmol} / \mathrm{L}$ ammonium chloride causes an increase in $\mathrm{pH}_{\mathrm{i}}$ owing to the rapid influx of $\mathrm{NH}_{3}$ into the cell. We have previously demonstrated that in a $\mathrm{HCO}_{3}{ }^{-} / \mathrm{CO}_{2}$-buffered solution, the initial rate of $\mathrm{pH}_{\mathrm{i}}$ recovery from alkalosis reflects the rate of $\mathrm{HCO}_{3}{ }^{-}$efflux across the apical membrane ${ }^{2}$. Figure $13 \mathrm{~A}$ shows $\mathrm{pH}_{\mathrm{i}}$ responses to ammonium chloride exposure in control, secretin-, and secretin plus SP-treated ducts, in $\mathrm{HCO}_{3}{ }^{-}$-buffered solution. Administration of $10 \mathrm{nmol} / \mathrm{L}$ secretin significantly increased basal secretion from $18.43 \pm 0.96$ to $47.72 \pm 1.72 \mathrm{mmol} / \mathrm{L}$ base per minute (Fig. $13 \mathrm{~A} ; \mathrm{p}<0.05$ ), whereas application of $20 \mathrm{nmol} / \mathrm{L}$ SP completely blocked the stimulatory effect of secretin $(23.84 \pm 1.91 \mathrm{mmol} / \mathrm{L}$ base per minute; Fig. 13A, B). Basolateral administration of the NK1 antagonist (RP67580) at a concentration of $10 \mu \mathrm{mol} / \mathrm{L}$, in the presence of secretin and SP did not influence the inhibitory effect of SP (Fig. 13B). However, the NK2 antagonist, MEN10376 (10 $\mu \mathrm{mol} / \mathrm{L})$ and the NK3 antagonist, SB218795 $(10 \mu \mathrm{mol} / \mathrm{L})$ significantly reversed the inhibitory effect of SP by $42.5 \pm 2.1 \%$ and $68.1 \pm 3.5 \%$, respectively (Fig. 13B). Simultaneous administration of MEN10376 and SB218795 did not produce any further block of the effect of SP (63.6 $\pm 0.3 \%$; Fig. 13B), indicating that other mechanisms may be involved. 
A

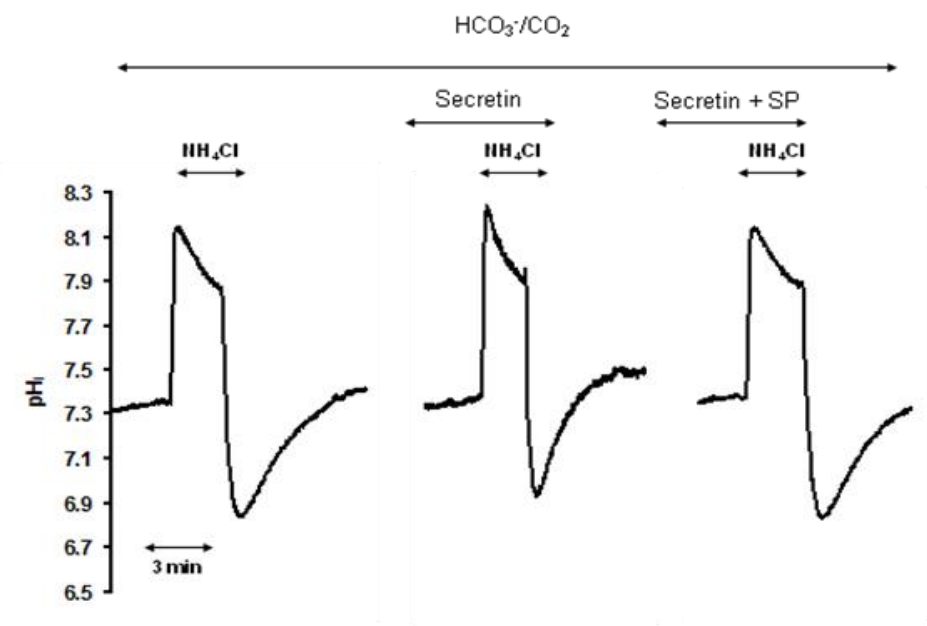

B

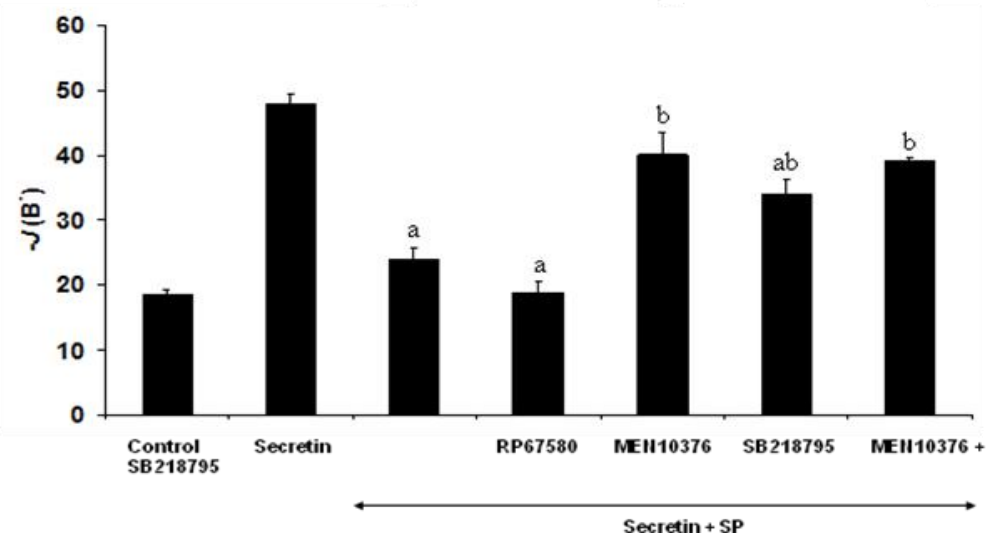

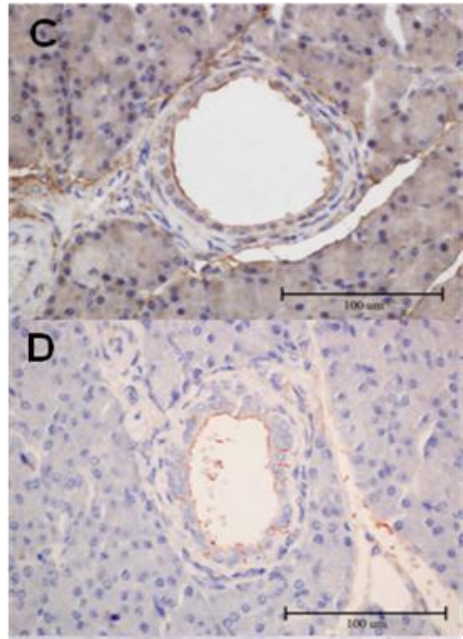

E

FIG 13. The inhibitory effect of SP on pancreatic ductal bicarbonate secretion is mediated by NK2 and NK3 receptors. A, Representative $\mathrm{pH}_{\mathrm{i}}$ curves of guinea pig pancreatic ductal cells showing the recoveries from alkali load. Ducts were alkali loaded by exposure to 3-minute pulse of $20 \mathrm{mmol} / \mathrm{L}$ ammonium chloride $\left(\mathrm{NH}_{4} \mathrm{Cl}\right)$ in a $\mathrm{HCO}_{3}{ }^{-} / \mathrm{CO}_{2}$-buffered solution. Initial rate of recovery from alkalosis over the first 30 seconds was calculated. All experiments were performed at $37^{\circ} \mathrm{C}$. In the control group, $20 \mathrm{mmol} / \mathrm{L} \mathrm{NH} \mathrm{Cl}_{4} \mathrm{Cl}$ was given alone in a $\mathrm{HCO}_{3}{ }^{-} / \mathrm{CO}_{2}$-buffered solution. Secretin $(10 \mathrm{nmol} / \mathrm{L})$, SP $(20 \mathrm{nmol} / \mathrm{L})$, and $\mathrm{NK}$ antagonists $(10 \mu \mathrm{mol} / \mathrm{L})$ were administered from 10 minutes before the exposure of $\mathrm{NH}_{4} \mathrm{Cl}$. B, Bar chart shows the summary of base effluxes $\left[-J\left(\mathrm{~B}^{-}\right)\right]$calculated from the alkali load experiments. Means \pm SEM for groups of 6 to 10 ducts are shown. Significant difference $(\mathrm{P}<0.05)$ : a, versus secretin and $\mathrm{b}$, versus secretin/SP. Immunohistochemistry showed luminal localization of NK1 (C) and lateral/luminal localizations of both NK2 (D) and NK3 (E) receptors in the guinea pig pancreas.

\section{Discussion}

The role of the stromal microenvironment is essential in tumor development and angiogenesis. The cells of this microenviroment, like stellate cells in pancreatic carcinomas 
or myofibroblasts in the gastric carcinomas, contribute to the progression of the diseases by producing inflammatory mediators, cytokines and collagens ${ }^{11,12,19}$. Tumor derived myofibroblasts have increased migration and proliferation rates compared to adjacent tissue myofibroblasts, and their cellular proteomes and secretomes differ as well ${ }^{58}$. Consequently, regulating stromal cells might lead to therapeutic drugs that can modify tumor development and growth. Therefore, in our study we focused on the $\mathrm{Ca}^{2+}$ homeostasis, migration and proliferation of HGMs.

In our study, we showed that oesophageal, gastric, duodenal and colonic myofibroblasts display spontaneous $\mathrm{Ca}^{2+}$ oscillations, whereas pancreatic myofibroblasts do not. However, it should be noted that the lack of oscillations in the pancreatic myofibroblasts might not reflect the physiological state in the human pancreas, as these specimens were isolated from a patient suffering in chronic pancreatitis. For that reason, the lack of oscillations might be due to the chronic inflammatory state, the damage from pancreatic enzymes or the significant amount of epithelial-mesenchymal transitions. However, further studies are needed to determine whether oscillations occur in healthy or tumor-derived pancreatic myofibroblasts. Among the oscillatory myofibroblasts the HGMs displayed the highest number of oscillations with the highest frequency. These oscillations depended on the extracellular concentrations of $\mathrm{Ca}^{2+}$ and $\mathrm{Na}^{+}$. As $\left[\mathrm{Na}^{+}\right]_{\mathrm{i}}$ did not vary in our experiments and the L-type $\mathrm{Ca}^{2+}$ channel blocker verapamil did not affect $\mathrm{Ca}^{2+}$ oscillations, the presence of any voltage mediated ion influx can be excluded. Oscillations did not depend on cell passage number or confluency on the carrier cover glasses. The function of this phenomenon is unknown; it may be related to muscle cell origin or it may probably designate a different state in cell cycle. However, our results suggest that cell cyle could not be the main reason for oscillations. Perhaps they are the result of cell division and migration together, which might explain the heterogeneity of oscillations. Our results suggest that nerve innervations are not required for oscillations or contractions of at least $50 \%$ of HGMs. Therefore, these cells should be considered to have nerve independent spontaneous oscillatory activity. Administration of carbachol (data not shown) caused a single elevation in $\mathrm{Ca}^{2+}$ concentration, but did not switch on the oscillatory activity of the cells. However, bioactive molecules (matrix metalloproteinases, TGF $\beta$, insulin-like growth factor binding protein-5, IGF-II progastrin, endothelin-1) were shown to modulate the proliferation and activation of stromal myofibroblasts ${ }^{12,15,59,60}$. Therefore, it is more likely, that these cells are rather regulated by themselves in an autonomous way and by 
bioactive molecules by their neighbouring cells (such as epithelial cells), thus contributing to inflammation and cancer progression.

In mouse embryonic stem cells $\mathrm{Ca}^{2+}$ oscillations are mediated by inositol 1,4,5-triphosphate and store-mediated $\mathrm{Ca}^{2+}$ entry ${ }^{61}$. However, in $\mathrm{HGMs} \mathrm{Ca}^{2+}$ clearly enters from the extracellular space, while in mouse embryonic stem cells oscillations may occur in the abscence of $\mathrm{Ca}^{2+}$ as well, depending on the cell cycle.

With ion-withdrawal techniques we showed that an extracellular $\mathrm{Na}^{+}$and $\mathrm{Ca}^{2+}$ dependent transport mechanism plays an important role in regulating the cytosolic $\mathrm{Ca}^{2+}$ and $\mathrm{Na}^{+}$levels in HGMs, suggesting the presence of NCX. By $\mathrm{K}^{+}$withdrawal technique we showed that the $\mathrm{Na}^{+}$and $\mathrm{Ca}^{2+}$ dependent transport is independent of $\mathrm{K}^{+}$, thus ruling out the involvement of $\mathrm{Na}^{+} / \mathrm{Ca}^{2+}-\mathrm{K}^{+}$exchangers in controlling the calcium homeostasis of HGMs. Our study indicates that extracellular $\mathrm{Mg}^{2+}$ might have a regulatory role in the $\mathrm{Ca}^{2+}$ oscillations, as the removal of $\mathrm{Mg}^{2+}$ causes $\mathrm{Ca}^{2+}$ oscillations in some non-oscillating cells. Probably that is due to the decreased intracellular $\mathrm{Mg}^{2+}$ concentration, which activates the $\mathrm{NCX}^{62}$. Furthermore, NCX mRNA and protein were expressed in HGMs. The NCX inhibitor CB-DMB (which inhibits the forward and reverse mode of NCX) stopped the oscillations even after washout of the agent, highlighting the non-competitive irreversible effect of $\mathrm{CB}-\mathrm{DMB}$. $\mathrm{NiCl}_{2}$, which is a competitive divalent anion for $\mathrm{Ca}^{2+}$ in eukaryotic cells ${ }^{63}$, caused cease of oscillations for the period of administration, but oscillation returned after washout.

In non-excitable HeLa cells, the mitochondrial NCX controls the pattern of cytosolic $\mathrm{Ca}^{2+}$ oscillations, but in that study cells were pre-treated with histamine to display oscillation ${ }^{64}$. In the same study in human fibroblasts, the mitochondrial NCX inhibitor CGP37157 increased the frequency of the baseline oscillations in cells having spontaneous activity and induced the generation of oscillations in cells without spontaneous activity. In HGMs, the possible role for mitochondrial NCX generated oscillation is unlikely, since CB-DMB does not inhibit mitochondrial $\mathrm{NCX}^{65}$.

Earlier work from $\mathrm{Jacob}^{66}$ showed that oscillations mediated by calcium-induced calcium release from endoplasmic reticulum (ER) in endothelial cells are synchronized in neighbouring cells. However, this was not the case in our experiments. In rabbit urethral interstitial cells of Cajal, the oscillations were abolished when ryanodine receptors were blocked with tetracaine or ryanodine, also suggesting the role of intracellular $\mathrm{Ca}^{2+}$ stores in originating oscillations ${ }^{67}$. However, that may not be the mechanisms by which HGMs generate oscillation since CB-DMB does inhibit nor mitochondrial nor ER $\mathrm{Ca}^{2+}$ 
channels/transporters in applied concentration ${ }^{65}$ and no oscillations could be observed after applying it. In pulmonary artery smooth muscle cells, NCX plays an important role in regulating cytosolic $\mathrm{Ca}^{2+}$ levels, however in these cells $\mathrm{Ca}^{2+}$ increases via the NCX and storeoperated entry ${ }^{26}$. Although NCX regulates the cytosolic $\mathrm{Ca}^{2+}$ in the HGMs in a similar way, store operated entry does not play a role in HGMs, as inhibiting the NCX result in $\mathrm{Ca}^{2+}$ depletion, not store depletion-mediated $\mathrm{Ca}^{2+}$ entry.

Our results indicate that the $\mathrm{Ca}^{2+}$ oscillations may be sustained by plasmalemmal NCX in HGMs. Our results demonstrate that NCX current was not detectable in HGMs, the administration of $10 \mathrm{mM} \mathrm{NiCl}_{2}$ did not influence the currents recorded in control conditions (in $\mathrm{K}^{+}$-free bath solution in the absence of $\mathrm{Ni}^{2+}$ ). In order to validate our experimental method, NCX current was measured in single cells isolated from left ventricles of dog hearts. The NCX current in myofibroblasts may be under the limit of our experimental sensitivity, which could be due to the low number or low density of NCX transporters in the plasma membrane of HGMs.

By controlling the intracellular $\mathrm{Na}^{+}$and $\mathrm{Ca}^{2+}$ levels in HGMs, NCX may regulate different important physiological processes. Therefore we investigated the effect of NCX inhibitors on the proliferation and migration rates of HGMs.

Migration was inhibited in HGMs under basal conditions following NCX inhibition by CBDMB and nickel chloride. It is clear that migrating cells need intracellular free $\mathrm{Ca}^{2+}$ for actin polymerization, which is necessary for the formation of lamellipodia ${ }^{68}$, suggesting that decreasing $\left[\mathrm{Ca}^{2+}\right]_{\mathrm{i}}$ might result in decreased motility. Furthermore, it has been shown that NCX1.1 associates with the F-actin cytoskeleton in NCX1.1 expressing Chinese hamster ovarian cells ${ }^{69}$.

There are other proteins like calpain and myosins which utilize $\left[\mathrm{Ca}^{2+}\right]_{\mathrm{i}}$ for organizing the construction of focal adhesions also necessary for migration ${ }^{70}$. It is believed that $\mathrm{Ca}^{2+}$ entry, mediated by store depletion, through the reverse mode of NCX increases $\left[\mathrm{Ca}^{2+}\right]_{\mathrm{i}}$, thus stimulating motility in rat tendon fibroblasts ${ }^{25}$. In Madin-Darby canine kidney cells, the plasma membrane calcium ATP-ase and particularly the NCX are necessary for cell migration, and the lack of NCX function almost fully abrogates migration ${ }^{71}$.

IGF-II acts through insulin-like growth factor receptor I receptor increasing motility via various ways, such as Akt, MAP and PI3, depending on the cell type ${ }^{72}$. IGF-II caused a twofold increase in motility of HGMs, which was decreased by both CB-DMB and $\mathrm{NiCl}_{2}$. These 
data suggest that NCX plays an important role not only in the basal, but also in the IGF-IIstimulated migration of HGMs.

Basal proliferation rates were also impaired by either CB-DMB or $\mathrm{NiCl}_{2}$ treatment. That may be a result of the above mentioned lack of free $\left[\mathrm{Ca}^{2+}\right]_{i}$, which is necessary for signalling key events in cytoskeletal organization during S-phase or M-phase ${ }^{73}$. Furthermore, without proper $\mathrm{Ca}^{2+}$ signaling, resting cells cannot get over the $\mathrm{G}_{0}$ phase ${ }^{74}$. In pulmonary artery smooth muscle cells, $\mathrm{Ca}^{2+}$ enters the cytosol after store depletion via the reverse-mode of NCX, and the NCX inhibitor KB-R7943 inhibited cell proliferation via disorganization of intracellular $\mathrm{Ca}^{2+}$ signalling ${ }^{26}$.

IGF-II treatment greatly increased cell division in HGMs. However, administering NCX inhibitors abrogated this effect. In addition, $\mathrm{NiCl}_{2}$ decreased both basal and IGF-II-stimulated proliferation to surprisingly low levels and we believe that besides blocking NCX, this effect might be due to the inhibition of other enzymes as well ${ }^{75}$. Thus we think that these effects of $\mathrm{NiCl}_{2}$ in long-term (24h) proliferation experiments may contribute to the decreased proliferation rates of HGMs. Therefore such an enzyme inhibitor effect in migration experiments also cannot be excluded.

In conclusion, we showed for the first time that cultured HGMs display non-synchronized spontaneous monophasic $\mathrm{Ca}^{2+}$ oscillations, which depend on the extracellular $\mathrm{Ca}^{2+}$ and $\mathrm{Na}^{+}$. In oscillatory and non-oscillatory $\mathrm{HGMs}\left[\mathrm{Ca}^{2+}\right]_{\mathrm{i}}$ and $\left[\mathrm{Na}^{+}\right]_{\mathrm{i}}$ are dependent on extracellular $\mathrm{Ca}^{2+}$ and $\mathrm{Na}^{+}$suggesting a role for NCX. We showed that NCX1, NCX2 and NCX3 mRNA and protein are present in HGMs and are involved in the migration and proliferation of HGMs. Functional experiments showed that NCX is necessary for proper basal and IGF-IIstimulated migration and particularly for proliferation of HGMs. As myofibroblasts are involved in pathophysiological conditions, such as chronic inflammation or tumor development, further investigations are needed to determine if modulating NCX function has a therapeutic effect on hyperproliferative gastric diseases.

Our lab has showed that ethanol in low concentration stimulates, whereas in high concentrations inhibits pancreatic ductal $\mathrm{HCO}_{3}{ }^{-}$secretion and decreases CFTR activity, thus contributing to the pathogenesis of pancreatitis. We further characterized the mechanism by which ethanol and its metabolites inhibit $\mathrm{HCO}_{3}{ }^{-}$secretion and CFTR activity. Low concentraction of ethanol $(10 \mathrm{mM})$ stimulated $\mathrm{HCO}_{3}{ }^{-}$secretion by $\mathrm{IP}_{3} \mathrm{R}$-dependent $\mathrm{Ca}^{2+}$ release from the ER. In contrast, high concentrations of ethanol and POA induced sustained $\left[\mathrm{Ca}^{2+}\right]_{i}$ elevation mediated by both the $\mathrm{IP}_{3} \mathrm{R}$ and $\mathrm{RyR}$ as well as extracellular $\mathrm{Ca}^{2+}$ influx. 
Our results indicate that POA completely depletes the $\mathrm{ER} \mathrm{Ca}^{2+}$ stores and induces extracellular $\mathrm{Ca}^{2+}$ influx, to sustain the elevated $\left[\mathrm{Ca}^{2+}\right]_{\mathrm{i}}$. Furthermore, POA not only depletes $\mathrm{ER} \mathrm{Ca}^{2+}$, but by decreasing PMCA activity, it decreases the removal of calcium from PDEC cells, contributing to the elevated $\left[\mathrm{Ca}^{2+}\right]_{\mathrm{i}}$. Notably, similar toxic $\mathrm{Ca}^{2+}$ elevation was found in pancreatic acinar cells, and in other cell types leading to premature protease activation and cell death ${ }^{41,76-79}$. It is well documented that sustained $\left[\mathrm{Ca}^{2+}\right]_{\mathrm{i}}$ elevation causes mitochondrial $\mathrm{Ca}^{2+}$ overload $^{40}$, which impairs mitochondrial membrane potential and ATP production ${ }^{41,42}$. Very recently ethanol was shown to sensitize pancreatic mitochondria to activate the mitochondrial permeability transition pore, leading to mitochondrial failure ${ }^{80}$. Our lab has shown that, high concentrations of ethanol and POA also induced $[\mathrm{ATP}]_{\mathrm{i}}$ depletion and decreased mitochondrial membrane potential. The toxic effects of ethanol and POA were similar to those of high concentration of bile acids ${ }^{7,81}$. In conclusion, we found that the POA induced sustained elevation of $\left[\mathrm{Ca}^{2+}\right]_{\mathrm{i}}$ is a combined result of the depletion of ER stores and the inhibition of PMCA activity in PDEC. These observations could explain why ethanol consumption damages PDEC cell function, that might contribute to the pathogenesis of acute pancreatitis.

It is known that SP inhibits basal and secretin-stimulated ductal fluid secretion ${ }^{45,46}$. This inhibitory effect may be physiologically important in limiting the hydrostatic pressure developed within the duct lumen during secretion and in turning off ductal secretion after a meal. Recently, we have shown that the inhibitory effect of SP can be partially reversed by spantide, a nonselective neurokinin (NK) receptor antagonist in the guinea pig pancreas ${ }^{47}$, indicating that NK receptors are involved in the inhibitory effect of SP. Furthermore, it has been shown that the inhibition of SP is mediated by protein kinase $\mathrm{C}$ and independent of calcium signaling, however it is not know which NK receptor subtype is involved in the regulation of ductal secretion ${ }^{8}$. SP is known to exert its effects via 3 distinct mammalian NK receptors subtypes, NK1, NK2, and NK $3^{48}$.

We characterized the localization of NK receptor subtypes in the guinea pig pancreas and showed that NK2 and NK3 receptors localize at the basal and lateral membrane of pancreatic duct cells, while NK1 receptors localize on the luminal side only. We provided evidence that SP inhibits bicarbonate secretion via both of the laterally expressed NK receptors, namely, NK2 and NK3, but not the luminal NK1. Our results, showing that all of the NK receptors are 
expressed in the luminal membrane of pancreatic ductal cells, open up new physiological questions, which need further investigations.

In conclusion, we have determined that NCX mediated calcium oscillation is required for the physiology of HGMs. Furthermore, we have concluded that POA can activate toxic calcium oscillations in PDEC that might contribute to the pathogenesis of ethanol induced pancreatitis. Moreover, we have identified that substance $\mathrm{P}$ inhibits bicarbonate secretion of pancreatic ducts via NK2 and NK3 receptors. 


\section{Summary}

Introduction: Ion transporters have a crucial role in modulating several cellular functions in the GI tract. Ion transporters modulating calcium level of cells have important roles is cellular signalling, thus they mediate proliferation, migration and survival of several cell types. As calcium might play different roles in different cell types, the main aims of this work were to further investigate the role of calcium ion transporters in the physiology of human gastric myofibroblasts (HGMs) and in the pathophysiology of PDEC and to further characterize the calcium independent neuroendocrine regulation of $\mathrm{HCO}_{3}{ }^{-}$transporters in pancreatic ductal secretion.

Methods: Myofibroblasts were isolated from specimens were obtained from patients undergoing gastric tumor resection surgery in the Department of Surgery, University of Szeged, Hungary. 4-8 week-old guinea pigs were sacrificed by cervical dislocation. Intra/interlobular ducts were isolated by enzymatic digestion and microdissection from guinea pig pancreas. Immunocytochemistry and immunhistochemistry was used to characterize the phenotype cultures myofibroblasts. RT-PCR and immunocytochemistry was used to show NCX expression of HGMs. NK receptor expression was analysed by immunohistochemistry of guinea pig pancreas samples. Intracellular $\mathrm{Ca}^{2+}\left(\left[\mathrm{Ca}^{2+}\right]_{i}\right)$ and $\mathrm{Na}^{2+}$ $\left(\left[\mathrm{Na}^{2+}\right]_{\mathrm{i}}\right)$ concentrations of HGMs or Capan-1 cells, intracellular $\mathrm{pH}\left(\mathrm{pH}_{\mathrm{i}}\right)$ of pancreatic ducts were determined by microfluorometry. The rate of bicarbonate secretion was estimated by the alkali load technique. To measure migration and proliferation of HGMs, scratch wound migration assay and EdU incorporation assay was done, respectively.

Results: We showed for the first time that cultured HGMs display non-synchronized spontaneous monophasic $\mathrm{Ca}^{2+}$ oscillations, which depend on the extracellular $\mathrm{Ca}^{2+}$ and $\mathrm{Na}^{+}$. We have identified NCX as a regulator of $\mathrm{Ca}^{2+}$ homeostasis of HGMs, and showed that NCX regulates migration and proliferation of HGMs. As myofibroblasts are involved in pathophysiological conditions, such as chronic inflammation or tumor development, further investigations are needed to determine if modulating NCX function has a therapeutic effect on hyperproliferative gastric diseases.

We found that palmitoleic acid (POA), a non-oxidative metabolite of ethanol, induced sustained elevation of intracellular calcium $\left(\left[\mathrm{Ca}^{2+}\right]_{\mathrm{i}}\right)$. in PDEC. We have identified the mechanism of the sustained $\left[\mathrm{Ca}^{2+}\right]_{\mathrm{i}}$.elevation, which is a combined result of the depletion of 
endoplasmic reticulum stores and the inhibition of plasma membrane $\mathrm{Ca}^{2+}$-ATPase activity in PDEC. As the prolonged increase in $\left[\mathrm{Ca}^{2+}\right]_{\mathrm{i}}$ can cause ATP depletion and mitochondrial injury to PDEC, these observations might explain why ethanol consumption might damage PDEC cell function, that might contribute to the pathogenesis of acute pancreatitis.

We showed that NK2 and NK3 receptors localize at the basal and lateral membrane of pancreatic duct cells in guinea pig pancreas, while NK1 receptors localize on the luminal side only. We provided evidence that SP inhibits bicarbonate secretion via both of the laterally expressed NK receptors, namely, NK2 and NK3, but not the luminal NK1. Our results, showing that all of the NK receptors are expressed in the luminal membrane of pancreatic ductal cells, open up new physiological questions, which need further investigations.

In conclusion, we have determined that NCX mediated calcium oscillation is required for the physiology of HGMs. Furthermore, we have concluded that POA can activate toxic calcium oscillations in PDEC that might contribute to the pathogenesis of ethanol induced pancreatitis. Moreover, we have identified that substance $\mathrm{P}$ inhibits bicarbonate secretion of pancreatic ducts via NK2 and NK3 receptors. 


\section{Acknowledgements}

I would like to thank all of the people who have helped and inspired me to do research and write this thesis.

I am grateful to Prof. Dr. Ábrahám György and Prof. Dr. Tibor Wittmann, the current and former head of the First Department of Medicine and to Prof. Dr. András Varró, the head of Department of Pharmacology and Pharmacotherapy, who gave me opportunity to work their Departments.

I would like express my deep and sincere gratitude to my supervisors Prof. Dr. Péter Hegyi and Dr. Viktória Venglovecz and for their continuous support and guidance. Their wide knowledge and their logical way of thinking have been of great value for me. Their understanding and encouragement provided a good basis for this present thesis.

I would also like to thank my colleagues and friends, Dr. Zoltán Rakonczay Jr., Dr. Andrea Schnúr, Dr. József Maléth, Dr. Mátyás Czepán, Dr. Andrea Geisz, Dr. Petra Pallagi, Dr. Klaudia Farkas, Zsolt Balla, Éva Kunstár, Dr. Balázs Kui, Máté Katona, Dr. Anita Balázs, Dr. Eszter Végh for all the emotional support, entertainment and care they provided.

This work would not have been possible to accomplish without the assistance of Edit Magyarné Pálfi, Tünde Pritz, Zsoltné Árva, Miklósné Árva, Zoltánné Fuksz and Etus Enyinginé.

I am deeply grateful to Prof. David Yule and his research team at the University of Rochester, NY, USA for their collaboration and to the Rosztoczy Foundation for their kind support.

This study was supported by the Hungarian National Development Agency (TÁMOP 4.2.1.B-09/1/KONV, 4.2.2-08/1/2008-0002 and 0013, TÁMOP-4.2.2.A-11/1/KONV-20120035, TÁMOP-4.2.2-A-11/1/KONV-2012-0052 TÁMOP-4.2.2.A-11/1/KONV-2012-0073, TÁMOP-4.2.4.A/2-11-1-2012-0001; TÁMOP- 4.2.4.A2-SZJÖ-TOK-13-0017), the North West Cancer Research Funds (NWCRF), the Hungarian Scientific Research Fund (K76844, K78311, K109756, NF100677, NF100677, NNF78851, NF105758 and PD78087), the MTASZTE Momentum Grant (LP2014-10/2014) the Hungarian Academy of Sciences (BO 00334/08/5, BO 00174/10/5 and BO 00174/10/5), the Rosztoczy Foundation, the AlfriedKrupp-von-Bohlen-und-Halbach-Foundation (Graduate Schools Tumour Biology and Free 
Radical Biology), the Deutsche Krebshilfe/ Dr. Mildred-Scheel-Stiftung (109102), the Deutsche Forschungsgemeinschaft (DFG GRK840- E3/E4, DFG GRK1947, MA 4115/12/3), the Federal Ministry of Education and Research (BMBF GANI-MED 03152061A and BMBF 0314107, 01ZZ9603, 01ZZ0103, 01ZZ0403, 03ZIK012) and the European Union (EU-FP-7: EPC-TM and EU-FP7-REGPOT-2010-1, EPC-TM-Net).

Lastly, I am grateful to my family for all their love, support, never-ending patience and encouragement. I dedicate this thesis to them. 


\section{References}

1. Berridge, M. J. Inositol trisphosphate and calcium signalling. Nature 361, 315-325 (1993).

2. McCleskey, E. W., Fox, A. P., Feldman, D. \& Tsien, R. W. Different types of calcium channels. J. Exp. Biol. 124, 177-190 (1986).

3. Sanders, K. M., Koh, S. D., Ro, S. \& Ward, S. M. Regulation of gastrointestinal motility-insights from smooth muscle biology. Nat Rev Gastroenterol Hepatol 9, 633-645 (2012).

4. Wei, C. et al. Calcium flickers steer cell migration. Nature 457, 901-905 (2009).

5. Wang, X., Takano, T. \& Nedergaard, M. Astrocytic calcium signaling: mechanism and implications for functional brain imaging. Methods Mol. Biol. 489, 93-109 (2009).

6. Pallagi-Kunstár, E. et al. Bile acids inhibit $\mathrm{Na}(+) / \mathrm{H}(+)$ exchanger and $\mathrm{Cl}(-) / \mathrm{HCO} 3(-)$ exchanger activities via cellular energy breakdown and $\mathrm{Ca}(2+)$ overload in human colonic crypts. Pflugers Arch. (2014). doi:10.1007/s00424-014-1560-9

7. Maléth, J. et al. Non-conjugated chenodeoxycholate induces severe mitochondrial damage and inhibits bicarbonate transport in pancreatic duct cells. Gut 60, 136-138 (2011).

8. Hegyi, P. et al. Protein kinase $\mathrm{C}$ mediates the inhibitory effect of substance $\mathrm{P}$ on HCO3secretion from guinea pig pancreatic ducts. Am. J. Physiol., Cell Physiol. 288, C1030$1041(2005)$.

9. Hinz, B. et al. The myofibroblast: one function, multiple origins. Am. J. Pathol. 170, 1807-1816 (2007).

10. Desmoulière, A., Chaponnier, C. \& Gabbiani, G. Tissue repair, contraction, and the myofibroblast. Wound Repair Regen 13, 7-12 (2005).

11. Hinz, B. The myofibroblast: paradigm for a mechanically active cell. $J$ Biomech 43, 146155 (2010).

12. Mutoh, H., Sashikawa, M., Hayakawa, H. \& Sugano, K. Monocyte chemoattractant protein-1 is generated via TGF-beta by myofibroblasts in gastric intestinal metaplasia and carcinoma without H. pylori infection. Cancer Sci. 101, 1783-1789 (2010).

13. Chai, J., Norng, M., Tarnawski, A. S. \& Chow, J. A critical role of serum response factor in myofibroblast differentiation during experimental oesophageal ulcer healing in rats. Gut 56, 621-630 (2007). 
14. Konturek, S. J. et al. Fibroblast growth factor in gastroprotection and ulcer healing: interaction with sucralfate. Gut 34, 881-887 (1993).

15. Nishida, T. et al. Endothelin-1, an ulcer inducer, promotes gastric ulcer healing via mobilizing gastric myofibroblasts and stimulates production of stroma-derived factors. Am. J. Physiol. Gastrointest. Liver Physiol. 290, G1041-1050 (2006).

16. Nakamura, M., Akiba, Y., Oda, M. \& Ishii, H. Appearance of myofibroblasts in the gastric mucosa after ingestion of ethanol and lansoprazole with reevaluation of the mucoid cap. Alcohol. Clin. Exp. Res. 22, 115S-120S (1998).

17. Guo, X., Oshima, H., Kitmura, T., Taketo, M. M. \& Oshima, M. Stromal fibroblasts activated by tumor cells promote angiogenesis in mouse gastric cancer. J. Biol. Chem. 283, 19864-19871 (2008).

18. McCaig, C. et al. The role of matrix metalloproteinase-7 in redefining the gastric microenvironment in response to Helicobacter pylori. Gastroenterology 130, 1754-1763 (2006).

19. De Wever, O., Demetter, P., Mareel, M. \& Bracke, M. Stromal myofibroblasts are drivers of invasive cancer growth. Int. J. Cancer 123, 2229-2238 (2008).

20. Quante, M. et al. Bone marrow-derived myofibroblasts contribute to the mesenchymal stem cell niche and promote tumor growth. Cancer Cell 19, 257-272 (2011).

21. Hawinkels, L. J. a. C. et al. Tissue level, activation and cellular localisation of TGF-beta1 and association with survival in gastric cancer patients. Br. J. Cancer 97, 398-404 (2007).

22. Rasmussen, H., Jensen, P., Lake, W. \& Goodman, D. B. Calcium ion as second messenger. Clin. Endocrinol. (Oxf) 5 Suppl, 11S-27S (1976).

23. Pietrobon, D., Di Virgilio, F. \& Pozzan, T. Structural and functional aspects of calcium homeostasis in eukaryotic cells. Eur. J. Biochem. 193, 599-622 (1990).

24. Blaustein, M. P. \& Lederer, W. J. Sodium/calcium exchange: its physiological implications. Physiol. Rev. 79, 763-854 (1999).

25. Sakamoto, K. et al. Involvement of $\mathrm{Na}+\mathrm{Ca} 2+$ exchanger in migration and contraction of rat cultured tendon fibroblasts. J. Physiol. (Lond.) 587, 5345-5359 (2009).

26. Zhang, S., Yuan, J. X.-J., Barrett, K. E. \& Dong, H. Role of Na+/Ca2+ exchange in regulating cytosolic $\mathrm{Ca} 2+$ in cultured human pulmonary artery smooth muscle cells. Am. J. Physiol., Cell Physiol. 288, C245-252 (2005). 
27. Romero, J. R. et al. Na+/Ca2+ exchanger activity modulates connective tissue growth factor mRNA expression in transforming growth factor beta1- and Des-Arg10-kallidinstimulated myofibroblasts. J. Biol. Chem. 280, 14378-14384 (2005).

28. Liao, J. et al. Structural insight into the ion-exchange mechanism of the sodium/calcium exchanger. Science 335, 686-690 (2012).

29. Linck, B. et al. Functional comparison of the three isoforms of the $\mathrm{Na}+\mathrm{Ca} 2+$ exchanger (NCX1, NCX2, NCX3). Am. J. Physiol. 274, C415-423 (1998).

30. Maléth, J. \& Hegyi, P. Calcium signaling in pancreatic ductal epithelial cells: an old friend and a nasty enemy. Cell Calcium 55, 337-345 (2014).

31. Yadav, D. \& Lowenfels, A. B. The epidemiology of pancreatitis and pancreatic cancer. Gastroenterology 144, 1252-1261 (2013).

32. Nagar, A. B. \& Gorelick, F. S. Acute pancreatitis. Curr. Opin. Gastroenterol. 18, 552557 (2002).

33. Braganza, J. M., Lee, S. H., McCloy, R. F. \& McMahon, M. J. Chronic pancreatitis. Lancet 377, 1184-1197 (2011).

34. Yadav, D. \& Lowenfels, A. B. Trends in the epidemiology of the first attack of acute pancreatitis: a systematic review. Pancreas 33, 323-330 (2006).

35. Pandol, S. J. \& Raraty, M. Pathobiology of alcoholic pancreatitis. Pancreatology 7, 105114 (2007).

36. Pandol, S. J. et al. Investigating the pathobiology of alcoholic pancreatitis. Alcohol. Clin. Exp. Res. 35, 830-837 (2011).

37. Petersen, O. H. et al. Fatty acids, alcohol and fatty acid ethyl esters: toxic $\mathrm{Ca} 2+$ signal generation and pancreatitis. Cell Calcium 45, 634-642 (2009).

38. Hegyi, P., Pandol, S., Venglovecz, V. \& Rakonczay, Z. The acinar-ductal tango in the pathogenesis of acute pancreatitis. Gut 60, 544-552 (2011).

39. Pallagi, P. et al. The role of pancreatic ductal secretion in protection against acute pancreatitis in mice*. Crit. Care Med. 42, e177-188 (2014).

40. Kroemer, G. \& Reed, J. C. Mitochondrial control of cell death. Nat. Med. 6, 513-519 (2000).

41. Criddle, D. N. et al. Fatty acid ethyl esters cause pancreatic calcium toxicity via inositol trisphosphate receptors and loss of ATP synthesis. Gastroenterology 130, 781-793 (2006). 
42. Walsh, C. et al. Modulation of calcium signalling by mitochondria. Biochim. Biophys. Acta 1787, 1374-1382 (2009).

43. Lee, M. G., Ohana, E., Park, H. W., Yang, D. \& Muallem, S. Molecular mechanism of pancreatic and salivary gland fluid and HCO3 secretion. Physiol. Rev. 92, 39-74 (2012).

44. Arkle, S., Lee, C. M., Cullen, M. J. \& Argent, B. E. Isolation of ducts from the pancreas of copper-deficient rats. Q J Exp Physiol 71, 249-265 (1986).

45. Hegyi, P. \& Rakonczay, Z. The inhibitory pathways of pancreatic ductal bicarbonate secretion. Int. J. Biochem. Cell Biol. 39, 25-30 (2007).

46. Ashton, N., Argent, B. E. \& Green, R. Effect of vasoactive intestinal peptide, bombesin and substance $\mathrm{P}$ on fluid secretion by isolated rat pancreatic ducts. J. Physiol. (Lond.) 427, 471-482 (1990).

47. Hegyi, P., Gray, M. A. \& Argent, B. E. Substance P inhibits bicarbonate secretion from guinea pig pancreatic ducts by modulating an anion exchanger. Am. J. Physiol., Cell Physiol. 285, C268-276 (2003).

48. Regoli, D., Drapeau, G., Dion, S. \& D’Orléans-Juste, P. Pharmacological receptors for substance P and neurokinins. Life Sciences 40, 109-117 (1987).

49. Czepán, M. et al. NHE1 activity contributes to migration and is necessary for proliferation of human gastric myofibroblasts. Pflugers Arch. 463, 459-475 (2012).

50. Argent, B. E., Arkle, S., Cullen, M. J. \& Green, R. Morphological, biochemical and secretory studies on rat pancreatic ducts maintained in tissue culture. Q J Exp Physiol 71, 633-648 (1986).

51. Venglovecz, V. et al. Effects of bile acids on pancreatic ductal bicarbonate secretion in guinea pig. Gut 57, 1102-1112 (2008).

52. Hegyi, P., Rakonczay, Z., Gray, M. A. \& Argent, B. E. Measurement of intracellular pH in pancreatic duct cells: a new method for calibrating the fluorescence data. Pancreas $\mathbf{2 8}$, 427-434 (2004).

53. Thomas, J. A., Buchsbaum, R. N., Zimniak, A. \& Racker, E. Intracellular pH measurements in Ehrlich ascites tumor cells utilizing spectroscopic probes generated in situ. Biochemistry 18, 2210-2218 (1979).

54. Varro, A. et al. The role of the delayed rectifier component IKs in dog ventricular muscle and Purkinje fibre repolarization. J. Physiol. (Lond.) 523 Pt 1, 67-81 (2000). 
55. Gomez-Pinilla, P. J. et al. Ano1 is a selective marker of interstitial cells of Cajal in the human and mouse gastrointestinal tract. Am. J. Physiol. Gastrointest. Liver Physiol. 296, G1370-1381 (2009).

56. Zhang, Y. et al. Dedifferentiation and proliferation of mammalian cardiomyocytes. PLoS ONE 5, e12559 (2010).

57. Bird, G. S., DeHaven, W. I., Smyth, J. T. \& Putney, J. W. Methods for studying storeoperated calcium entry. Methods 46, 204-212 (2008).

58. Holmberg, C. et al. Release of TGFßig-h3 by gastric myofibroblasts slows tumor growth and is decreased with cancer progression. Carcinogenesis 33, 1553-1562 (2012).

59. Duckworth, C. A. et al. Progastrin-induced secretion of insulin-like growth factor 2 from colonic myofibroblasts stimulates colonic epithelial proliferation in mice. Gastroenterology 145, 197-208, e3 (2013).

60. Hemers, E. et al. Insulin-like growth factor binding protein-5 is a target of matrix metalloproteinase-7: implications for epithelial-mesenchymal signaling. Cancer Res. 65, 7363-7369 (2005).

61. Kapur, N., Mignery, G. A. \& Banach, K. Cell cycle-dependent calcium oscillations in mouse embryonic stem cells. Am. J. Physiol., Cell Physiol. 292, C1510-1518 (2007).

62. Wei, S., Quigley, J. F., Hanlon, S. U., O’Rourke, B. \& Haigney, M. C. P. Cytosolic free magnesium modulates $\mathrm{Na} / \mathrm{Ca}$ exchange currents in pig myocytes. Cardiovasc. Res. 53, 334-340 (2002).

63. Iwamoto, T. \& Shigekawa, M. Differential inhibition of $\mathrm{Na}+\mathrm{Ca} 2+$ exchanger isoforms by divalent cations and isothiourea derivative. Am. J. Physiol. 275, C423-430 (1998).

64. Hernández-SanMiguel, E. et al. The mitochondrial $\mathrm{Na}+/ \mathrm{Ca} 2+$ exchanger plays a key role in the control of cytosolic Ca2+ oscillations. Cell Calcium 40, 53-61 (2006).

65. Secondo, A. et al. Molecular pharmacology of the amiloride analog 3-amino-6-chloro-5[(4-chloro-benzyl)amino]-n-[[(2,4-dimethylbenzyl)-amino]iminomethyl]-

pyrazinecarboxamide (CB-DMB) as a pan inhibitor of the $\mathrm{Na}+\mathrm{Ca} 2+$ exchanger isoforms NCX1, NCX2, and NCX3 in stably transfected cells. J. Pharmacol. Exp. Ther. 331, 212221 (2009).

66. Jacob, R. Calcium oscillations in endothelial cells. Cell Calcium 12, 127-134 (1991).

67. Johnston, L., Sergeant, G. P., Hollywood, M. A., Thornbury, K. D. \& McHale, N. G. Calcium oscillations in interstitial cells of the rabbit urethra. J. Physiol. (Lond.) 565, 449$461(2005)$. 
68. Downey, G. P., Chan, C. K., Trudel, S. \& Grinstein, S. Actin assembly in electropermeabilized neutrophils: role of intracellular calcium. J. Cell Biol. 110, 19751982 (1990).

69. Condrescu, M. \& Reeves, J. P. Actin-dependent regulation of the cardiac $\mathrm{Na}(+) / \mathrm{Ca}(2+)$ exchanger. Am. J. Physiol., Cell Physiol. 290, C691-701 (2006).

70. Bhatt, A., Kaverina, I., Otey, C. \& Huttenlocher, A. Regulation of focal complex composition and disassembly by the calcium-dependent protease calpain. J. Cell. Sci. 115, 3415-3425 (2002).

71. Dreval, V., Dieterich, P., Stock, C. \& Schwab, A. The role of Ca2+ transport across the plasma membrane for cell migration. Cell. Physiol. Biochem. 16, 119-126 (2005).

72. Petley, T., Graff, K., Jiang, W., Yang, H. \& Florini, J. Variation among cell types in the signaling pathways by which IGF-I stimulates specific cellular responses. Horm. Metab. Res. 31, 70-76 (1999).

73. Fresu, M., Bianchi, M., Parsons, J. T. \& Villa-Moruzzi, E. Cell-cycle-dependent association of protein phosphatase 1 and focal adhesion kinase. Biochem. J. 358, 407-414 (2001).

74. Berridge, M. J. Calcium signalling and cell proliferation. Bioessays 17, 491-500 (1995).

75. Snow, E. T., Xu, L. S. \& Kinney, P. L. Effects of nickel ions on polymerase activity and fidelity during DNA replication in vitro. Chem. Biol. Interact. 88, 155-173 (1993).

76. Criddle, D. N. et al. Ethanol toxicity in pancreatic acinar cells: mediation by nonoxidative fatty acid metabolites. Proc. Natl. Acad. Sci. U.S.A. 101, 10738-10743 (2004).

77. Kouzoukas, D. E. et al. Intracellular calcium plays a critical role in the alcohol-mediated death of cerebellar granule neurons. J. Neurochem. 124, 323-335 (2013).

78. Nakayama, N., Eichhorst, S. T., Müller, M. \& Krammer, P. H. Ethanol-induced apoptosis in hepatoma cells proceeds via intracellular $\mathrm{Ca}(2+)$ elevation, activation of TLCKsensitive proteases, and cytochrome c release. Exp. Cell Res. 269, 202-213 (2001).

79. Krüger, B., Albrecht, E. \& Lerch, M. M. The role of intracellular calcium signaling in premature protease activation and the onset of pancreatitis. Am. J. Pathol. 157, 43-50 (2000).

80. Shalbueva, N. et al. Effects of oxidative alcohol metabolism on the mitochondrial permeability transition pore and necrosis in a mouse model of alcoholic pancreatitis. Gastroenterology 144, 437-446.e6 (2013). 
81. Maléth, J., Rakonczay, Z., Venglovecz, V., Dolman, N. J. \& Hegyi, P. Central role of mitochondrial injury in the pathogenesis of acute pancreatitis. Acta Physiol (Oxf) 207, 226-235 (2013). 
Annex 


\section{Calcium szignalizáció szerepe a gasztrointesztinális traktusban}

\section{Bevezetés}

A gasztrointesztinális rendszer élettanában kiemelt fontosságal bírnak a különböző ion transzporterek. Calcium csatornák és transzporterek a sejten belüli calcium szintjének szabályozásával számos szignalizációs úton keresztül befolyásolják a sejtek migrációját, proliferációját és túlélését, míg a $\mathrm{HCO}_{3}{ }^{-}$transzporterek az egyik legfontosabb szabályozó elemei a pankreász duktális sejtjeinek folyadék szekréciójának.

\section{Célkitüzések}

Munkacsoportunk célul tüzte ki a calcium transzporterek és calcium homeosztázis jelentőségének vizsgálatát humán gyomor miofibroblasztokban, a calcium transzporterek szerepének tanulmányozását a pankrász duktális epitélsejt sejtjeinek patofiziológiájában, valamint a pankreász duktális $\mathrm{HCO}_{3}{ }^{-}$szekréció calciumtól független neuroendokrin szabályozásának további jellemzését. Specifikus céljaink:

1. A humán gyomor miofibroblasztok calcium homeosztázisában szerepet játszó ion transzporter(ek) azonosítása, továbbá ezen ion transzporter(ek) szerepének vizsgálata a miofibroblasztok migrációjában és proliferációjában.

2. Az etanol egy non-oxidatív metobolitjának, a palmitoleinsavnak hosszan tartó calcium szint emelő hatásának vizsgálata pankreász duktális sejtjein, valamint a calcium szintet befolyásoló ion transzporterek azonosítása.

3. Tengerimalac pankreász neurokinin (NK) receptor altípusainak kifejeződésének vizsgálata, valamint a substance $\mathrm{P}$ bikarbonát szekréciót gátló hatását közvetítő NK altípusok azonosítása.

\section{Anyagok és Módszerek}

A miofibroblasztok izolálása az SZTE ÁOK Sebészeti Klinikáján gyomor rezekciós mütéten átesett betegek mintáiból történt. A miofibroblasztok fenotípusának jellemzése 
immuncitokémia és immunhisztokémia segítségével történt. A nátrium-calcium kicserélő kimutatása fehérje szinten immunfluoreszcens eljárással, RNS szinten reverz transzkripciót követő PCR segítségével történt. A miofibroblasztok proliferációjának vizsgálata EdU inkorporáció, migrációjának kvantifikálása karc-sebzést követő migráció mérésével történt.

4-8 hetes tengerimalacokból cervikális diszkolációt követően történt a pankreász elvátolítása, majd intra/interlobuláris duktuszok izolálása enzimatikus emészést követően mikrodisszekcióval történt. A tengerimalac pankreászok neurokinin receptor expresszióját immunhisztokémiával vizsgáltuk.

A Capan-1 pankreász duktális sejtek intracelluláris calcium, a miofibroblasztok calcium és nátrium koncentrációjának, valamint a tengerimalac pankreász duktuszok intracelluláris pH-jának változását mikrofluorometriával detektáltuk. A duktuszok bikarbonát szekréciójának mérésére az ammonium-pulzus technikát használtuk.

\section{Eredmények}

\section{Nátrium-calcium kicserélő szerepének vizsgálata a gyomor miofibroblasztok migrációjában és proliferációjában}

1. Gasztrointesztinális rendszer különböző részeiből izolált fibroblasztok egy része spontán, nem szinkronizált calcium oszcillációkat végez.

2. Immuncitokémia segítségével megállapítottuk, hogy az izolált miofibroblasztok nem azonosak a gasztrointesztinális rendszerben megtalálható Cajal sejtekkel, mivel a Cajal sejt marker DOG1-et nem fejezik ki.

3. Az intracelluláris calcium oszcillációk az extracelluláris calciumtól és nátriumtól függenek.

4. A nátrium-calcium kicserélő mindhárom izoformája (NCX1, NCX2, NCX3) kifejeződik a gyomor miofibroblasztokban mind RNS, mind fehérje szinten.

5. NCX gátlószerek alkalmazása megszünteti a miofibroblasztok spontán oszcillácóját. 
6. NCX gátlószerek alkalmazása csökkenti a gyomor miofibroblasztok migrációja.

7. NCX gátlása csökkenti a gyomor miofibroblasztok proliferációját.

\section{A palmitoleinsav tartós calcium szintet emelő hatásának vizsgálata}

1. A palmitoleinsav az extracelluláris calcium beáramlásának elősegítésével és az endoplazmatikus reticulum kiürítésével emeli a pankreász duktális sejtek intracelluláris calcium szintjét.

2. A palmitoleinsav a plazma membrán calcium ATP-áz aktivitásának gátlásával is hozzájárul a calcium szint magasan tartásához, mivel csökkenti a calcium kiáramlását a duktális sejtekből.

\section{A substance $P$ bikarbonát szekréciót gátló hatását közvetítő neurokinin receptorok vizsgálata}

1. A NK2 és NK3 receptorok a pankreász duktuszok bazolaterális oldalán, míg az NK1 receptor a duktuszok luminális oldalán fejeződik ki.

2. A substance P a NK2 és NK3 receptorokon keresztül gátolja a pankreász duktuszok bikarbonát szekrécióját.

\section{Következtetések}

A gasztrointesztinális rendszer számos különböző sejttípusában vizsgáltuk a calcium homeosztázis és ion transzporterek szerepét. Azonosítottuk a nátrium-calcium kicserőlőt (NCX), mint a gyomor miofibroblasztok calcium homeosztázisának egyik kulcs transzporterét. Megállapítottuk, hogy az NCX gátlásával csökken a miofibroblasztok migrációja és proliferációja, így az NCX potenciális terápiás célpontként szolgálhat különböző hiperproliferatív gasztroenterológiai kórképekben. Továbbá kimutattuk, hogy az etanol egy non-oxidatív metabolitja, a palmitoleinsav az endoplazmatikus retikulum kiürítésével, az extracelluláris calcium beáramlásának fokozásával és a plazma membrán calcium ATP-áz gátlásával tartja magasan a pankreász duktális epithel sejtjeinek calcium szintjét, potenciálisan hozzájárulva az epithelium alkohol indukált sejtkárodosáshoz és az 
alkoholos pankreátitiszhez. Valamint eredményeink hozzájárultak a fiziológiás pankreász nedv elválasztás szabályozásának pontosabb megértéséhez, mivel azonosítottuk, hogy a substance $\mathrm{P}$ az NK2 és NK3 receptorokon keresztül gátolja a pankreász folyedék szekrécióját. 
Articles closely related to the thesis 